\title{
Ecological principles underlying the increase of productivity achieved by cereal-grain legume intercrops in organic farming. A review
}

\author{
Laurent Bedoussac • Etienne-Pascal Journet • Henrik Hauggaard-Nielsen • \\ Christophe Naudin • Guenaelle Corre-Hellou • Erik Steen Jensen • \\ Loïc Prieur • Eric Justes
}

Accepted: 27 November 2014 / Published online: 10 April 2015

(C) INRA and Springer-Verlag France 2015

\begin{abstract}
World population is projected to reach over nine billion by the year 2050, and ensuring food security while mitigating environmental impacts represents a major agricultural challenge. Thus, higher productivity must be reached through sustainable production by taking into account climate change, resources rarefaction like phosphorus and water, and losses of fertile lands. Enhancing crop diversity is increasingly recognized as a crucial lever for sustainable agro-ecological development. Growing legumes, a major biological nitrogen source, is also a powerful option to reduce synthetic nitrogen fertilizers use and associated fossil energy consumption. Organic farming, which does not allow the use of chemical, is also regarded as one prototype to enhance the sustainability of
\end{abstract}

\author{
L. Bedoussac $(\bowtie)$ \\ ENFA, 2 route de Narbonne-BP 22687, 31326 Castanet-Tolosan, \\ France \\ e-mail: laurent.bedoussac@toulouse.inra.fr \\ L. Bedoussac $\cdot$ E.-P. Journet $\cdot$ E. Justes \\ INRA, UMR 1248 AGIR, Castanet-Tolosan, France \\ E.-P. Journet \\ CNRS, UMR 2594 LIPM, Castanet-Tolosan, France \\ H. Hauggaard-Nielsen \\ Department of Environmental, Social and Spatial Change, Roskilde \\ University, Roskilde, Denmark \\ C. Naudin · G. Corre-Hellou \\ LUNAM Université, Groupe ESA, UR LEVA - SFR 4207 QUASAV, \\ Angers, France \\ E. S. Jensen \\ Department of Biosystems and Technology, Swedish University of \\ Agricultural Sciences, Alnarp, Sweden \\ L. Prieur \\ CREAB Midi-Pyrénées, LEGTA, Auch, France
}

modern agriculture while decreasing environmental impacts. Here, we review the potential advantages of eco-functional intensification in organic farming by intercropping cereal and grain legume species sown and harvested together. Our review is based on a literature analysis reinforced with integration of an original dataset of 58 field experiments conducted since 2001 in contrasted pedo-climatic European conditions in order to generalize the findings and draw up common guidelines. The major points are that intercropping lead to: (i) higher and more stable grain yield than the mean sole crops $(0.33$ versus $0.27 \mathrm{~kg} \mathrm{~m}^{-2}$ ), (ii) higher cereal protein concentration than in sole crop (11.1 versus $9.8 \%$ ), (iii) higher and more stable gross margin than the mean sole crops ( 702 versus $577 € \mathrm{ha}^{-1}$ ) and (iv) improved use of abiotic resources according to species complementarities for light interception and use of both soil mineral nitrogen and atmospheric $\mathrm{N}_{2}$. Intercropping is particularly suited for low-nitrogen availability systems but further mechanistic understanding is required to propose generic crop management procedures. Also, development of this practice must be achieved with the collaboration of value chain actors such as breeders to select cultivars suited to intercropping.

Keywords Environmental resource use - Eco-functional intensification $\cdot$ Cereal-grain legume intercrop $\cdot$ Protein concentration $\cdot$ Weed $\cdot$ Yield

Contents

1. Introduction

2.Advantages expected by cereal/legume intercropping

2.1. Intercropping is more efficient than sole crops for grain production

2.2. Intercropping increases total grain production 
2.3. Intercropping improves the protein concentration of the cereal grain

2.4. Intercropping reduce weeds compared to the sole cropped legumes

3. Interactions between species and complementary use of $\mathrm{N}$ sources

3.1. Competition, complementarity and facilitation for use of resources

3.2. Intercropping with a non-legume increases the rate of atmospheric $\mathrm{N}_{2}$ fixation but reduces the quantity of nitrogen fixed on an area basis

3.3. Complementary use of nitrogen pools

3.4. Improved light interception

3.5. Acquisition of nitrogen and light: two intimately linked processes

4. Greatest intercrop advantages in low-input systems

4.1. The lower the soil nitrogen availability, the greater the intercrop efficiency

4.2. Cereal grain protein concentration in IC depends on sole crop quality, yield reduction and soil mineral use by the legume

5. Designing appropriate crop management systems and crop rotations

5.1. General principles

5.2. Designing crop management according to production objectives

5.3. Densities, spatial structure and nitrogen fertilization

6. Economic benefits and variability of intercropping

7. Conclusion and perspectives

8. References

\section{Introduction}

World population is projected to reach over nine billion by the year 2050 which represents a major challenge to global agriculture (FAO 2010), especially considering sustainability issues in order to ensure the availability of resources for the next generations in a context of climate change. Achieving greater plant diversity within agricultural systems is increasingly recognized as an important pillar of sustainable development (IAASTD 2009; Davies et al. 2009). About 7000 species have been used to a significant extent by humans over the world (Walter and Lebot 2003) while only 82 crop species provide $90 \%$ of the energy consumed by humans (Prescott-Allen and Prescott-Allen 1990). Nevertheless, restoring a high cropspecific and genetic diversity will be difficult to achieve over the next 40 years (Pardey and Pingali 2010) because most of these traditional crops and varieties are unattractive in comparison to modern, valuable and high-yielding crops. As a consequence, agriculture must exploit the technologies developed over the last half century based on genetic improvement and inputs but prevent loss of varietal diversity, fossil consumption or excessive use of agrochemicals which are known to contribute to global warming (Kim and Dale 2005), soil, air and water contaminations or loss of beneficial biodiversity like pollinators.

These increasing concerns about environmental impacts and reduction of inputs require a transformation of current cropping systems for improved efficiency and sustainability (Cox and Atkins 1979; Jackson and Piper 1989; Vandermeer et al. 1998; Griffon 2006). Organic farming is thus regarded as one prototype to enhance the sustainability of present agriculture and cereal-rich cropping systems because organic farming does not allow the use of chemicals and is also in general assumed to rely on higher crop diversity than its conventional counterpart. Indeed, diversification of farming systems by increasing the number of cultivated species and including a larger proportion of legumes was proposed as a global response to the challenges of future agriculture (Vandermeer 1995; Vandermeer et al. 1998; Altieri 1999; Griffon 2006; Malézieux et al. 2009). Instead of using synthetic nitrogen fertilizers to increase farmland productivity in the short term and the overall farm production like for the Green Revolution, new systems could be designed based on symbiotic $\mathrm{N}_{2}$ fixation by legumes. That was the case of some European farming systems in the 1950s where as much as $50 \%$ of all available $\mathrm{N}$ may have originated directly from symbiotic $\mathrm{N}_{2}$ fixation by leguminous food, forage and green manure crops (Peoples et al. 2009). In those systems, land was dedicated to fertilitygenerating legume rotations, which potentially also contributed to other ecosystem services such as carbon sequestration and biodiversity (Peoples et al. 2009). Moreover, exploiting the leguminous symbiotic fixation of atmospheric $\mathrm{N}_{2}$ as a major nitrogen source is a main objective also because it means that less $\mathrm{N}$ fertilizer input is required (Fustec et al. 2010), reducing $\mathrm{CO} 2$ emissions (Nieder and Benbi 2008) and lowering the carbon footprints of agricultural products (Gan et al. 2011). Legumes are of a particular interest in organic farming where nitrogen availability is often limiting especially in the absence of livestock (David et al. 2005) causing yield depressions and lower protein concentrations of non-legume products as compared to conventional agriculture.

Despite these advantages, grain legume cropping is less favoured now, even in organic crop rotations, because of a reputation of low yield and instability related to several factors like intolerance to water stress, harvest difficulties because of lodging, pathogen attacks causing diseases such as Ascochyta spp., Botrytis spp. or Erysiphe spp., sensitivity to insect pests like Sitona lineatus L. or Acyrthosiphon pisum Harris and weed competition. Morever, there may be other limitations in the interest for grain legume cropping because, for example, the subsequent cereal crops following legumes in the rotation might result in lower grain yields and protein concentration as compared to cereals grown with a more direct nitrogen fertilization using mineral fertilizers or animal manure. 
Aiming at higher crop diversity, intercropping is an interesting option. It is defined as the simultaneous growth of two or more species in the same field for a significant period of time (Willey 1979a) but without necessarily sowing or harvesting at the same time (Vandermeer et al. 1998; Malézieux et al. 2009). Niggli et al. (2009) describe intercropping as an eco-functional intensification practice which has been widely used to boost crop productivity (Qin et al. 2013), increase the land utilization ratio (Agegnehu et al. 2008) and emit significantly lower amounts of greenhouse gases compared to sole crops (e.g. Oelhermann et al. 2009; Naudin et al. 2014). Intercropping is of particular interest in temperate regions where organic arable crop rotations consist mainly of sole crops, i.e. pure stands, including annual legumes (Hauggaard-Nielsen et al. 2001b) with a number of abiotic and biotic factors influencing yields. Indeed, the cereallegume interactions based on functional complementarity could be a more suitable way to obtain stable yields along with simultaneous atmospheric nitrogen inputs as compared to the more classical introduction of legumes as sole crops (Hauggaard-Nielsen et al. 2009b).

Due to the intensification of agriculture during the last 50 years (Crews and Peoples 2004), annual intercropping is now rare in European countries, the more diverse pastures in farming systems with livestock being an exception (Hauggaard-Nielsen et al. 2001b). Intercropping is also rare elsewhere in extensive farming systems (Anil et al. 1998; Malézieux et al. 2009) while grass-clover mixtures are the norm in non-cultivated and more natural grassland ecosystems. However, there seems to be a renewed interest in cereal/ legume intercrops in Europe, most notably in organic farming (Anil et al. 1998; Malézieux et al. 2009). Enhancing diversity through the use of alternative crops, diversifying agroecosystems and rotations or cultivating mixtures is also more likely to fulfil multiple objectives like, for example: (i) increasing yield and quality of grain and forage, (ii) providing ecological services, (iii) improving adaptability of production systems to climate change (IAASTD 2009) and (iv) potentially allowing a greater resilience of systems to biotic and abiotic stresses (Padulosi et al. 2002).

The main objective of this article is to describe and analyse the potential advantages of cereal-grain legume intercrops with species sown and harvested together in organic cropping systems focusing on grain yield, grain protein concentration, nitrogen use, weed control and economic gross margin. Our work integrates a comprehensive amount of original data (Table 1) from field experiments conducted since 2001 in south and west France and Denmark in experimental and farm contexts with contrasting soil and climatic conditions (Figs. 1 and 2, respectively). Both spring and winter cereal/grain legume intercrops were evaluated with barley (Hordeum vulgare L.), soft wheat (Triticum aestivum L.) and durum wheat (Triticum turgidum L.) intercropped with pea (Pisum sativum L.) or faba bean (Vicia faba L.). Experiments covered a wide range of management practices such as with or without organic $\mathrm{N}$ fertilization, sowing species in separate rows or within the same row and considering different sowing proportions.

This data material altogether with an important bibliographic analysis both for conventional and organic farming gives a unique possibility to generate generic value on the efficiency and functioning of cereal/grain legume intercrops. Intercrops were always compared with the corresponding sole crops sown on the same date, receiving the same $\mathrm{N}$ fertilization and harvested at the later crop maturity in intercrops. When a $\mathrm{N}$-fertilized sole crop legume was not included in the experimental design, the unfertilized legume sole crop was considered as the control, assuming that $\mathrm{N}$ was not a limiting resource and thereby not influencing yields, as demonstrated on peas (Sagan et al. 1993; Voisin et al. 2002). This hypothesis could be invalidated when weevils occurred and caused damage to nodules at the end of the growing season and when there was a negative interaction between $\mathrm{N}$-fertilization and $\mathrm{N}_{2}$ fixation on total $\mathrm{N}$ supply. Feasibility and potential limitations of intercropping will also be carefully addressed in order to qualify the feasibility of transforming organic farming existing practices.

\section{Advantages expected by cereal/legume intercropping}

Numerous agroecosystems advantages are expected by introducing cereal/legume intercropping as compared to the traditional and dominating cereal-rich crops rotations (Hauggaard-Nielsen and Jensen 2005). The most obvious advantages emphasized when trying to convince farmers to adopt intercropping strategies are to improve and stabilize yields (Hauggaard-Nielsen et al. 2009b; Lithourgidis et al. 2006) and also to increase the cereal grain protein concentration as compared to the respective sole crops (Gooding et al. 2007). Cereal/legume intercropping is regarded as highly relevant in low-N-input systems and organic farming where nitrogen is often a limiting resource for crop growth (Willey 1979a; Ofori and Stern 1987; Vandermeer 1989; Willey 1990; Fukai and Trenbath 1993; HauggaardNielsen et al. 2003; David et al. 2005; Desclaux et al. 2008; Bedoussac and Justes 2010a, 2010b; Naudin et al. 2010). Intercropping has also been shown to: (i) improve soil conservation (Anil et al. 1998), (ii) favour weed control (Banik et al. 2006; Corre-Hellou et al. 2011), (iii) reduce pests and diseases (Trenbath 1993; Altieri 1999; Hauggaard-Nielsen et al. 2007; Corre-Hellou and Crozat 2005; Ratnadass et al. 2012) and (iv) provide better lodging resistance (Anil et al. 1998). 
Table 1 List of field experiments analysed in this paper

\begin{tabular}{|c|c|c|c|c|c|c|c|c|}
\hline Crops & $\begin{array}{l}\text { Cereal } \\
\text { species }\end{array}$ & $\begin{array}{l}\text { Legume } \\
\text { species }\end{array}$ & Year & Location & $\begin{array}{l}\text { Sites (per } \\
\text { location) }\end{array}$ & $\begin{array}{l}\mathrm{N} \\
\text { treatment }\end{array}$ & $\begin{array}{l}\text { Intercrop densities } \\
\text { (\% of sole crop) }\end{array}$ & Cultivar: cereal/legume \\
\hline \multirow[t]{15}{*}{ Writer crops } & \multirow[t]{5}{*}{ Hard wheat } & \multirow[t]{5}{*}{ Pea } & 2009 & $\begin{array}{l}\text { South of France } \\
\quad \text { (Toulouse area) }\end{array}$ & 1 & $\mathrm{~N}$ & $58-93$ & Dakter/Enduro \\
\hline & & & 2009 & $\begin{array}{l}\text { South of France } \\
\quad \text { (Toulouse area) }\end{array}$ & 1 & NO & $58-93$ & Acalou/Livia \\
\hline & & & 2009 & $\begin{array}{l}\text { South of France } \\
\quad \text { (Toulouse area) }\end{array}$ & 1 & NO & $58-93$ & Dakter/Enduro \\
\hline & & & 2010 & $\begin{array}{l}\text { South of France } \\
\quad \text { (Toulouse area) }\end{array}$ & 1 & $\mathrm{~N}$ & $58-72$ & Dakter/Cartouche \\
\hline & & & 2010 & $\begin{array}{l}\text { South of France } \\
\quad \text { (Toulouse area) }\end{array}$ & 1 & NO & $58-72$ & Dakter/Enduro \\
\hline & \multirow[t]{4}{*}{ Hard wheat } & \multirow[t]{4}{*}{ Faba bean } & 2009 & $\begin{array}{l}\text { South of France } \\
\quad \text { (Toulouse area) }\end{array}$ & 1 & NO & $58-49$ & Dakter/Irena \\
\hline & & & 2009 & $\begin{array}{l}\text { South of France } \\
\quad \text { (Toulouse area) }\end{array}$ & 2 & NO & $58-49$ & L1823/Irena \\
\hline & & & 2009 & $\begin{array}{l}\text { South of France } \\
\quad \text { (Toulouse area) }\end{array}$ & 1 & NO & $58-49$ & Duetto/Irena \\
\hline & & & 2010 & $\begin{array}{l}\text { South of France } \\
\quad \text { (Toulouse area) }\end{array}$ & 2 & NO & $66-50$ & Dakter and L1823/Castel \\
\hline & \multirow[t]{6}{*}{ Soft wheat } & \multirow[t]{6}{*}{ Pea } & $2003 ; 2005$ & $\begin{array}{l}\text { West of France } \\
\text { (Angers area) }\end{array}$ & 1 & NO & $50-100 ; 50-50$ & Apache/Lucy \\
\hline & & & 2006 & $\begin{array}{l}\text { South of France } \\
\text { (Toulouse area) }\end{array}$ & 1 & $\mathrm{~N} ; \mathrm{NO}$ & $50-50$ & Caphorn/Arthur \\
\hline & & & 2009 & $\begin{array}{l}\text { South of France } \\
\quad \text { (Toulouse area) }\end{array}$ & 1 & NO & $30-70 ; 50-50$ & PR22R58/Livia \\
\hline & & & 2010 & $\begin{array}{l}\text { South of France } \\
\quad \text { (Toulouse area) }\end{array}$ & 2 & $\mathrm{~N}$ & $58-72$ & Aerobic/Enduro \\
\hline & & & 2010 & $\begin{array}{l}\text { South of France } \\
\quad \text { (Toulouse area) }\end{array}$ & 1 & NO & $30-70 ; 50-50$ & PR22R58/Enduro \\
\hline & & & 2010 & $\begin{array}{l}\text { South of France } \\
\text { (Toulouse area) }\end{array}$ & 2 & NO & $58-72$ & Aerobic/Enduro \\
\hline \multirow[t]{6}{*}{ Spring crops } & Soft wheat & Faba bean & $2003 ; 2004$ & Denmark (Taastrup) & 1 & $\mathrm{NO} ; \mathrm{N}$ & $100-100 ; 50-50$ & \\
\hline & \multirow[t]{4}{*}{ Barley } & \multirow[t]{4}{*}{ Pea } & $2001 ; 2002 ; 2003$ & Denmark (Taastrup) & 1 & NO & $50-50$ & Otira/Agadir and Bohatyr \\
\hline & & & $2003 ; 2004 ; 2005$ & $\begin{array}{l}\text { West of France } \\
\text { (Angers area) }\end{array}$ & 1 & NO & $50-100 ; 50-50$ & Scarlett/Baccara \\
\hline & & & $2003 ; 2004 ; 2005$ & Denmark (Taastrup) & 1 & NO & $50-100 ; 50-50$ & Scarlett/Baccara \\
\hline & & & $2009 ; 2010$ & $\begin{array}{l}\text { South of France } \\
\quad \text { (Toulouse area) }\end{array}$ & 1 & NO & $30-70 ; 50-50$ & Nevada/Livia \\
\hline & Barley & Faba bean & $2001 ; 2002 ; 2003$ & Denmark (Taastrup) & 1 & NO & $50-50$ & Otira/Columbo \\
\hline
\end{tabular}

Six intercrops were evaluated at 13 different sites in France (southern and western areas) and Denmark representing 58 treatments. For each trial we indicate the cereal and legume densities in intercrop as a percentage of the sole crop densities, $\mathrm{N}$ treatment and cultivars. More information about experiments can be found in Hauggaard-Nielsen et al. (2007); (2001a, 2001b); Knudsen et al. (2004) and Naudin et al. (2009)

$H W$ durum wheat, $S W$ soft wheat, $B$ barley, $F$ faba bean, $P$ pea, $N O$ no N-fertilization $N$ organic N-fertilization

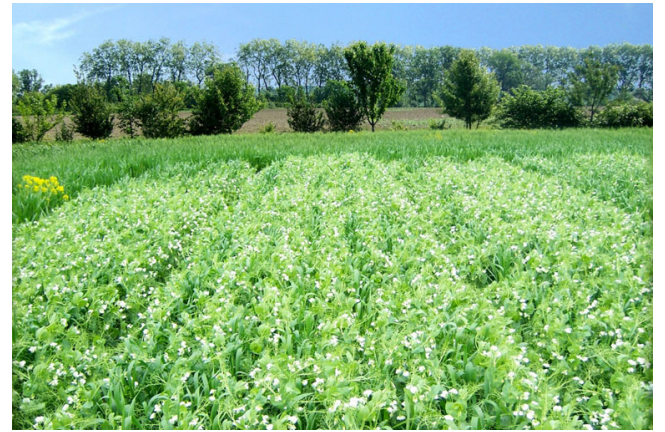

Fig. 1 Durum wheat-winter pea intercrop in experimental field. South of France

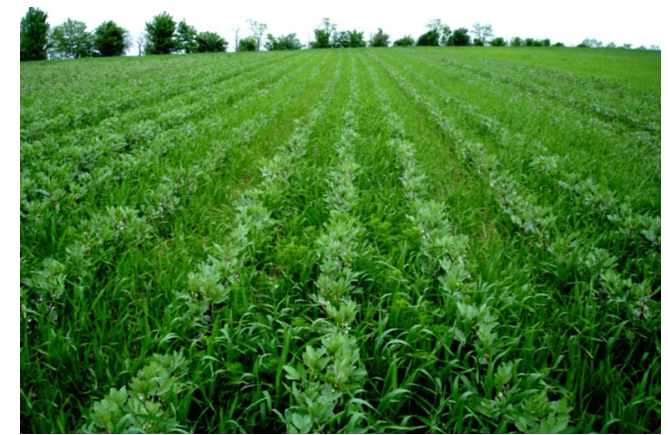

Fig. 2 Durum wheat-winter faba bean intercrop in organic farm field. South of France 
2.1 Intercropping is more efficient than sole crops for grain production

The land equivalent ratio (LER; Willey and Osiru 1972) is widely used in about $11 \%$ of articles on intercrop or intercropping published between 2000 and 2010 to compare the efficiency of sole crops and intercrops for yield, dry weight or any quantitative variable of production. More precisely, the LER is defined as the relative land area required when growing sole crops to produce, for example, the yield achieved in an intercrop with the same species proportion (Willey and Osiru 1972). LER $>1$ indicates a per-area advantage to intercropping compared to sole cropping in terms of improved use of environmental resources such as light, water and nitrogen.

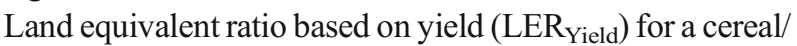
legume intercrop is the sum of the partial LER values for cereal ( $\left.\mathrm{LER}_{\text {Yield-Cereal }}\right)$ and legume ( $\left.\mathrm{LER}_{\text {Yield-Legume }}\right)$, in accordance with Willey and Osiru (1972):

$$
\begin{aligned}
\mathrm{LER}_{\text {Yield }} & =\mathrm{LER}_{\text {Yield-Cereal }}+\mathrm{LER}_{\text {Yield-Legume }} \\
& =\frac{\text { Yield }_{\text {Cereal-Intercrop }}}{\text { Yield }_{\text {Cereal-Solecrop }}}+\frac{\text { Yield }_{\text {Legume-Intercrop }}}{\text { Yield }_{\text {Legume-Solecrop }}}
\end{aligned}
$$

Nevertheless, as pointed out by Williams and McCarthy (2001), the full potential of the LER index is rarely explored. Indeed, it is usually simply used to investigate whether the intercrop is producing more than sole crops on similar area. This index could be much more useful. It can picture the competitive advantage of one species against the other intercrop component as well as mutual negative interactions or facilitation interactions, in particular when plotting partial LER values of legume as a function of those of the cereal.

Grain yield-based LER values in this data set are greater than 1 (1.27 on average) for almost all the experiments (Fig. 3). This confirms results obtained both in conventional and organic farming that show an improvement in the use of environmental factors for plant growth in intercropping compared with the respective sole crops. Our results also demonstrate the wide variability in LER ranging between 0.93 and 2.41 across experiments, with $50 \%$ of the observations lying between 1.06 and 1.36 without being able to identify more efficient species or proportion treatments. Moreover, $16 \%$ of the treatments stand in the figure area corresponding to situations in which the legume grows better on a per plant basis in the intercrop and suppresses the cereal. These situations correspond to a partial land equivalent ratio for the legume higher than its density ratio in IC relatively to the sole crop; this result is simultaneously obtained with a partial land equivalent ratio for the cereal lower than its density ratio in IC relatively to the sole crop. The reverse is true in $48 \%$ of the treatments while
Yield land equivalent ratio for legume and cereal

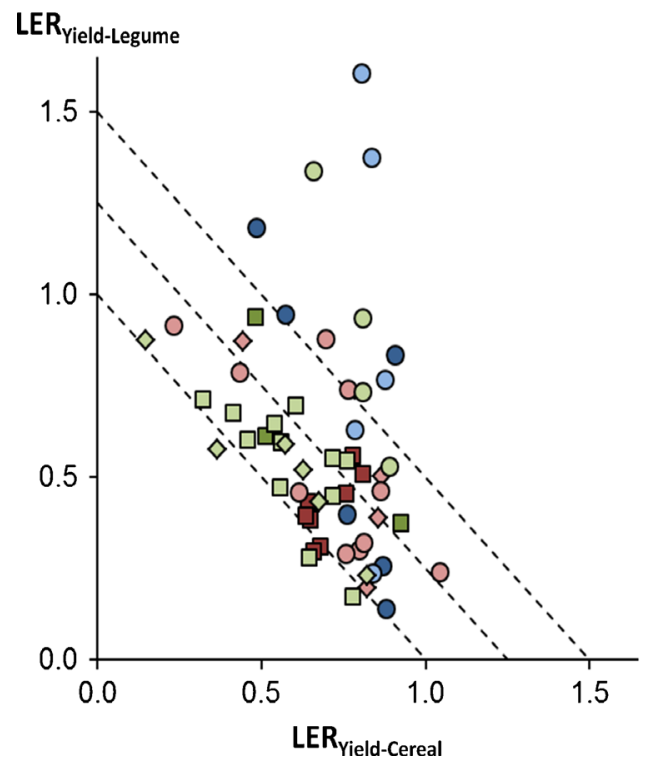

Fig. 3 Partial land equivalent ratio based on the grain yield for the legume ( $\left(\mathrm{LER}_{\text {Yield-Legume }}\right)$ as a function of that for the cereal $\left(\mathrm{LER}_{\text {Yield- }}\right.$ Cereal). Colour symbols refers to the cereal (red soft wheat, blue hard wheat and green barley). Symbol brightness indicates the legume component (dark faba bean and clear pea). Symbol shape corresponds to the experimental site (circle South of France, diamond West of France and square Denmark). $N=58$. We observed that grain yield-based LER values are greater than 1 for almost all the experiments (1.27 on average) indicating an advantage to intercropping compared to sole cropping in terms of improved use of environmental resources such as light, water and nitrogen per cropped area unit. Moreover, $48 \%$ of the treatments correspond to situations in which the cereal grown better in the intercrop and suppresses the legume while the reverse is true in only $16 \%$ of the treatments. These situations correspond to a partial legume LER lower than its density ratio of IC relatively to the sole crop; this result is simultaneously obtained with a cereal partial LER higher than its density ratio of IC relatively to the sole crop

only $10 \%$ corresponds to situation where both species are suppressed in the mixture due to intra and interspecific competitive interactions. Finally, in the last $26 \%$ of the treatments, both species grow better in the mixture on a per-plant basis than they do as sole crops, indicating so-called facilitation. Note that when a species is sown in intercrop at the same density as in the sole crop, it always grows less than in the sole crop indicating lack of complementarity between intercropped species (Willey 1979a, 1979b).

The land equivalent ratio is a relevant indicator, not to interpret interactions but to quantify mixture productivity as compared to the sole crop situation (Jolliffe 2000) because it is dependent on the sole crop reference (Mead and Willey 1980; Jolliffe 2000). For that reason, LER values must always be related to the original data values and in particular those of the sole crop since relative and absolute production performances are not necessarily linked. For example, species mixtures with highest LER values do not necessarily have highest absolute productivity (Garnier et al. 1997; Jolliffe and Wanjau 1999). 
Many others indices are relevant for evaluating species interactions and intercrop efficiency (Weigelt and Jolliffe 2003), and a comparison of commonly used indices has been done by Bedoussac and Justes (2011) on durum wheat-winter pea intercrops.

\subsection{Intercropping increases total grain production}

Intercropping increases grain yield in organic farming over a wide range of grain yields $\left(0.06-0.57 \mathrm{~kg} \mathrm{~m}^{-2}\right)$. In fact, the total grain yield of the intercrop corresponding to the cereal plus the legume is nearly always ( $91 \%$ of our experiments) higher than the mean yield of the respective sole crops $(0.33 \pm$ 0.10 and $0.27 \pm 0.09 \mathrm{~kg} \mathrm{~m}^{-2}$, respectively; Fig. 4a). Relative yield of mixtures (RYM) - defined as the ratio of the total yield of the intercrop to the mean yield of the pure crops (Wilson 1988) - is on average $1.30 \pm 0.26$, with values lying between 0.93 and 2.06. The total average intercrop yield is greater (in $64 \%$ of our experiments) than the sole cropped cereal $\left(0.29 \pm 0.09 \mathrm{~kg} \mathrm{~m}^{-2}\right.$; Fig. 4 b) and greater (in $83 \%$ of our experiments) than the sole cropped legume $(0.24 \pm$ $0.14 \mathrm{~kg} \mathrm{~m}^{-2}$; Fig. $4 \mathrm{c}$ ). Moreover, the advantage of the intercrops seems to be greater when the yield of one or both of the respective sole crops is quite low, thus suggesting that intercropping could be a more suitable way to obtain stable yields in organic farming and low-nitrogen availability systems. These results confirm those obtained both in conventional agriculture and organic farming showing a higher grain yield in intercrop when comparing to the respective sole crops and in particular for cereal/legume mixtures (e.g. Jensen 1996a; Bedoussac and Justes 2010a, 2010b; HauggaardNielsen et al. 2009a, 2009b).

In most situations, the intercropped cereal is more productive than the intercropped legume independently of the cropping strategy (Fig. 5). Moreover, the more the cereal grain yield increased when intercropped, the less the legume yielded suggesting that there is a trade-off within the two crop yields. However, the relation is not linear indicating that in our

Fig. 4 Total grain yield $\left(\mathrm{kg} \mathrm{m}^{-2}\right)$ of the intercrop (IC; cereal +legume) as a function of $\mathbf{a}\left(y=0.95 x+0.08 ; R^{2}=0.74 * * *\right)$ mean sole crop grain yields, b $\left(y=0.74 x+0.11 ; R^{2}=0.48 * * *\right)$ sole crop cereal grain yield and $\mathbf{c}(y=$ $\left.0.48 x+0.22 ; R^{2}=0.44^{* * *}\right)$ sole crop legume grain yield. Colour symbols refers to the cereal (red soft wheat, blue hard wheat and green barley). Symbol brightness indicates the legume component (dark faba bean and clear pea). Symbol shape corresponds to the experimental site (circle South of France, diamond West of France and square Denmark). N=58. The total grain yield of the intercrop is a higher than the mean yield of the respective sole crops in $91 \%$ of our experiments $\left(0.33\right.$ and $0.27 \mathrm{~kg} \mathrm{~m}^{-2}$ respectively), b greater than the sole cropped cereal in $64 \%$ of our experiments $\left(0.29 \mathrm{~kg} \mathrm{~m}^{-2}\right)$ and $\mathbf{c}$ greater than the sole cropped legume in $83 \%$ of our experiments $\left(0.24 \mathrm{~kg} \mathrm{~m}^{-2}\right)$. Moreover, the advantage of the intercrops seems to be higher when the yield of one or both of the respective sole crops is quite low suggesting that intercropping could be a more suitable way to obtain stable yields in organic farming

\section{Intercrop grain yield compared to that of sole crops}
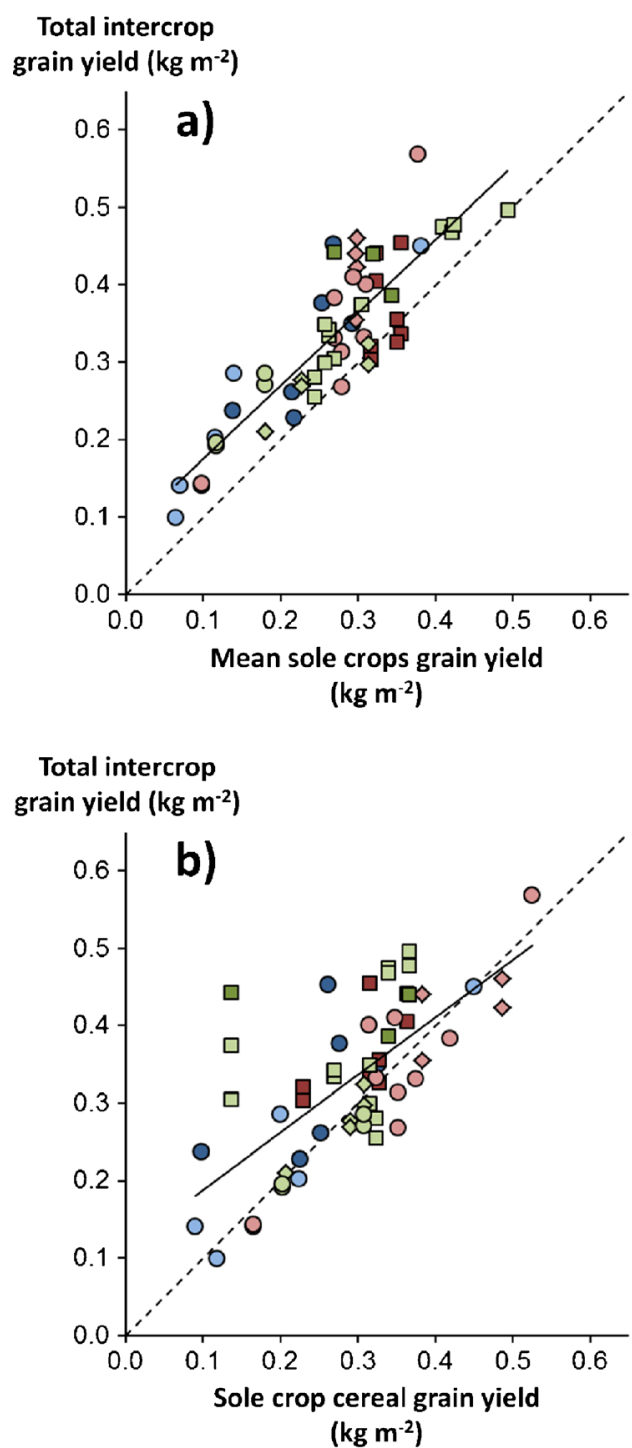

Total intercrop grain yield $\left(\mathrm{kg} \mathrm{m}^{-2}\right)$

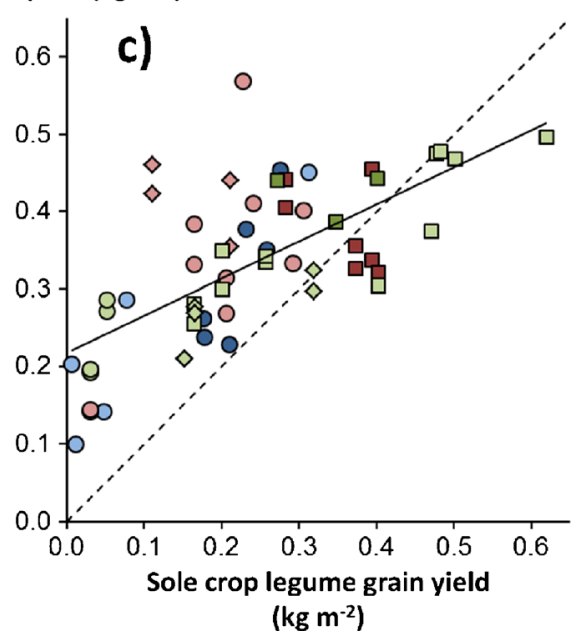


conditions, the dominant crop always provides a niche giving a minimum amount of grain yield produced by the dominated crop. The fact that the cereal is dominant in the intercrop can be partially explained by the productivity of the sole cropped cereal higher than that of the sole cropped legume. Nevertheless, the proportion of cereal in the intercrop is greater than that calculated on the basis of the sole crop yields only (3.9 versus 2.5 ; Fig. $6 \mathrm{a}$ ) and this is also true when correcting sole crop yields values by species density in intercrop relatively to the sole crops (3.9 versus 1.9; Fig. 6b). This indicates that the intercropped cereal most often took an advantage when growing with legumes confirming that the cereal is the most competitive species independent of cropping strategy (Vandermeer et al. 1998).

\subsection{Intercropping improves the protein concentration} of the cereal grain

Fulfilling the cereal nitrogen demand is crucial for obtaining profitable yield and grain protein concentration (GarridoLestache et al. 2004). Consequently, cereals are generally

\section{Cereal and legume grain yield in intercrop}

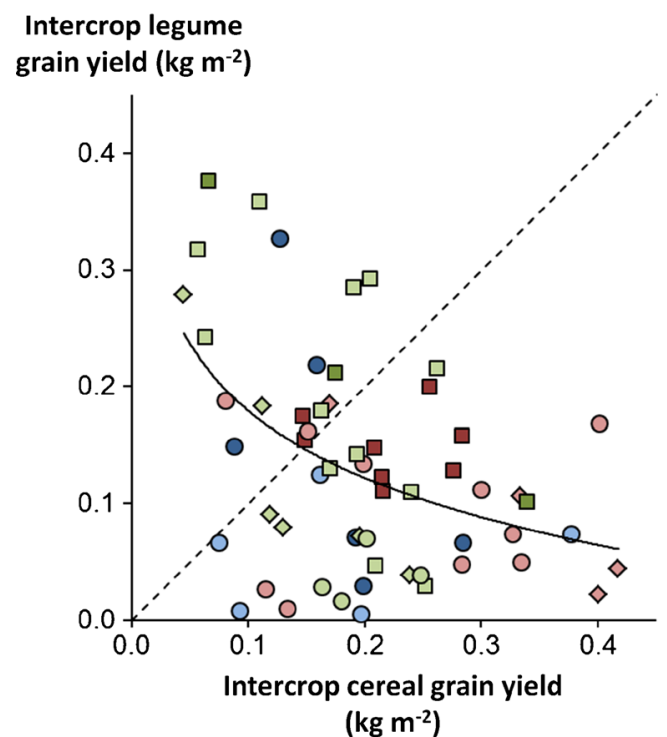

Fig. 5 Intercrop (IC) legume grain yield $\left(\mathrm{kg} \mathrm{m}^{-2}\right)$ as a function of the IC cereal grain yield $\left(y=-0.08 \ln (x)-0.01 ; R^{2}=0.20^{* * *}\right)$. Colour symbols refers to the cereal (red soft wheat, blue hard wheat and green barley). Symbol brightness indicates the legume component (dark faba bean and clear pea). Symbol shape corresponds to the experimental site (circle South of France, diamond West of France and square Denmark). $N=58$. In most of the situations, the intercropped cereal is more productive than the intercropped legume independently of the cropping strategy. Moreover, the more the cereal grain yield increased when intercropped, the less the legume yielded suggesting that there is a trade-off between the two crops yield. However, the relation indicates that in our conditions, the dominant crop always provides a niche giving a minimum amount of grain yield produced by the dominated crop

\section{Cereal grain yield proportion in intercrop and sole crop considering or not relative sowing densities}
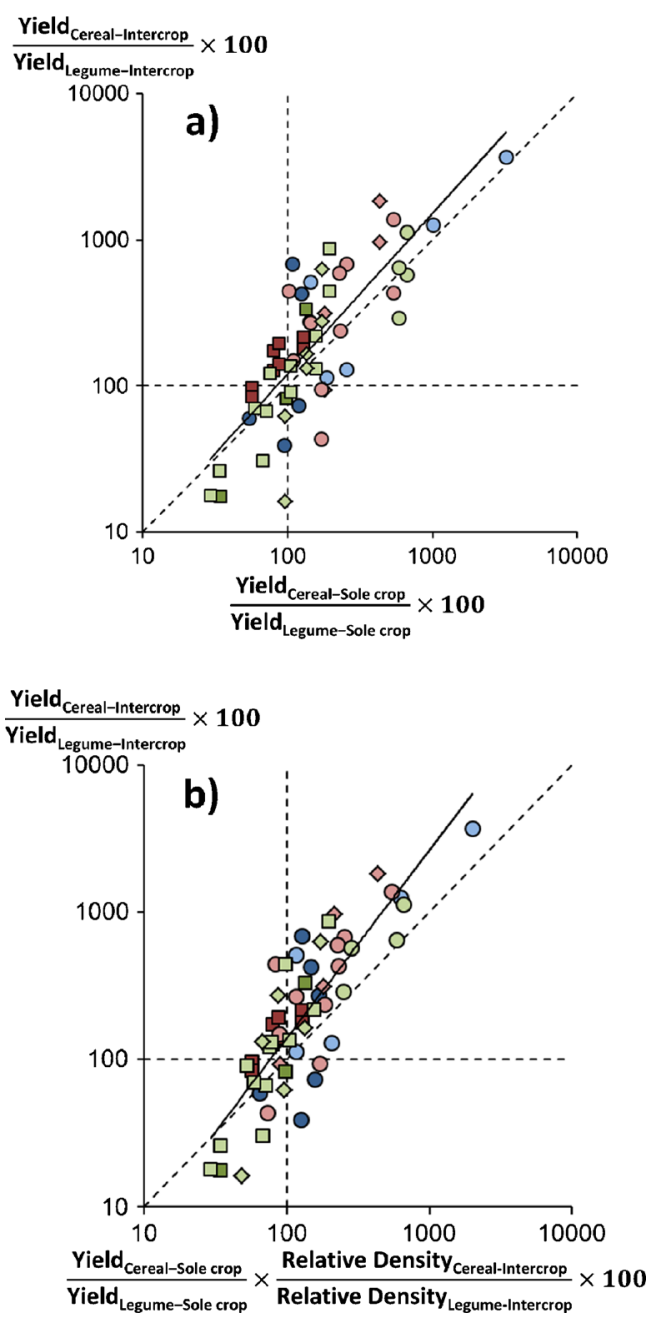

Fig. 6 Cereal/legume yield ratio in intercrop as a function of that for sole crops $\left(\mathbf{a} ; y=0.77 x^{1.10} ; R^{2}=0.63^{* * *}\right)$ and cereal/legume yield ratio in intercrop as a function of that for sole crops corrected by species relative density ( $\%$ of the sole crop densities) in intercrop (b; $y=$ $0.40 x^{1.27} ; R^{2}=0.70^{* * *}$ ). Colour symbols refers to the cereal (red soft wheat, blue hard wheat and green barley). Symbol brightness indicates the legume component (dark faba bean and clear pea). Symbol shape corresponds to the experimental site (circle South of France, diamond West of France and square Denmark). $N=58$. The proportion of cereal in the intercrop is a greater than that calculated on the basis of sole crops yields only (3.9 versus 2.5 ) and also $\mathbf{b}$ greater than that calculated on the basis of the sole crops yields correcting values by species density in intercrop relatively to the sole crops (3.9 versus 1.9$)$. Altogether, this indicates that the intercropped cereal most often took an advantage when growing with legumes independent of cropping strategy. This confirms that the cereal is the most competitive species which can be partially explained by the productivity of the sole cropped cereal higher than that of the sole cropped legume

fertilized with high levels of nitrogen not only in conventional cropping systems but also in organic systems using considerable amounts of organic inputs like animal manure, green 
manuring etc. On the contrary, in lower-nitrogen-input systems, limiting nitrogen resource makes it difficult to reach a sufficient grain protein concentration as required by agro-food industries either for soft wheat to make bread or for durum wheat to make semolina and pasta. Thus, in order to avoid a low durum wheat kernel vitreousness (Garrido-Lestache et al. 2004) which makes it unsuitable for high-quality semolina production (Samaan et al. 2006), it is necessary to increase the amounts of remobilized nitrogen into the grain during the final part of the crop cycle. Yet, as we indicated above, intercrops would be a way of improving harvested grain quality and in particular its protein concentration compared with the traditional sole cropping (e.g. Jensen 1996a; Knudsen et al. 2004; Gooding et al. 2007; Bedoussac and Justes 2010a; Naudin et al. 2010). Our results confirm that the protein concentration of the intercropped cereal is almost always greater than that of the respective cereal sole crop (Fig. 7a), with a mean of 11.1 versus $9.8 \%$. For durum wheat/winter pea intercrops, the biggest advantage of the intercrop is observed for low grain protein concentration of the sole cropped wheat due to limited availability of nitrogen during growth, thus confirming intercrops benefits in low-nitrogen availability systems (Bedoussac and Justes 2010a). Naudin et al. (2010) show that unfertilized wheat/winter pea intercrops can produce wheat protein concentrations not significantly different from sole cropped wheat fertilized with $18.5 \mathrm{~g} \mathrm{~N} \mathrm{~m}^{-2}$. In the case of legumes (Fig. 7b), no difference in average protein concentration could be observed between sole crops and intercrops (24.9\% in both cases) certainly due to the ability of the legumes to fulfil their nitrogen requirements by $\mathrm{N}_{2}$ fixation.

\subsection{Intercropping reduce weeds compared to the sole cropped legumes}

Intercrops can potentially reduce weeds, diseases and pests (Trenbath 1993; Altieri 1999) often regarded as determinant factors influencing crop production (Liebman 1988; White and Scott 1991; Liebman and Dyck 1993; Midmore 1993; Bulson et al. 1997; Liebman and Davis 2000; HauggaardNielsen et al. 2001b). In particular, grain legumes, such as peas ( $P$. sativum L.), are known to be weak competitors against weeds when grown as the sole crop (Wall et al. 1991; Townley-Smith and Wright 1994; Mcdonald 2003), and weed infestations have been shown to severely limit the $\mathrm{N}$ nutrition and grain yield of organically grown grain legumes (Corre-Hellou and Crozat 2005). Our results show that weed biomass below the intercrops or the cereal sole crops at harvest are comparable $\left(0.04 \mathrm{~kg} \mathrm{~m}^{-2}\right.$; Fig. $\left.8 \mathrm{a}\right)$ but significantly lower than below the legume sole crops $\left(0.14 \mathrm{~kg} \mathrm{~m}^{-2}\right.$; Fig. 8b). These results are consistent with those obtained by Corre-Hellou et al. (2011) on pea/barley intercrops where the weed suppression was high and consistent even with a low percentage of barley in the total biomass, whereas it was lower
Cereal and legume grain protein concentration in intercrop and sole crops
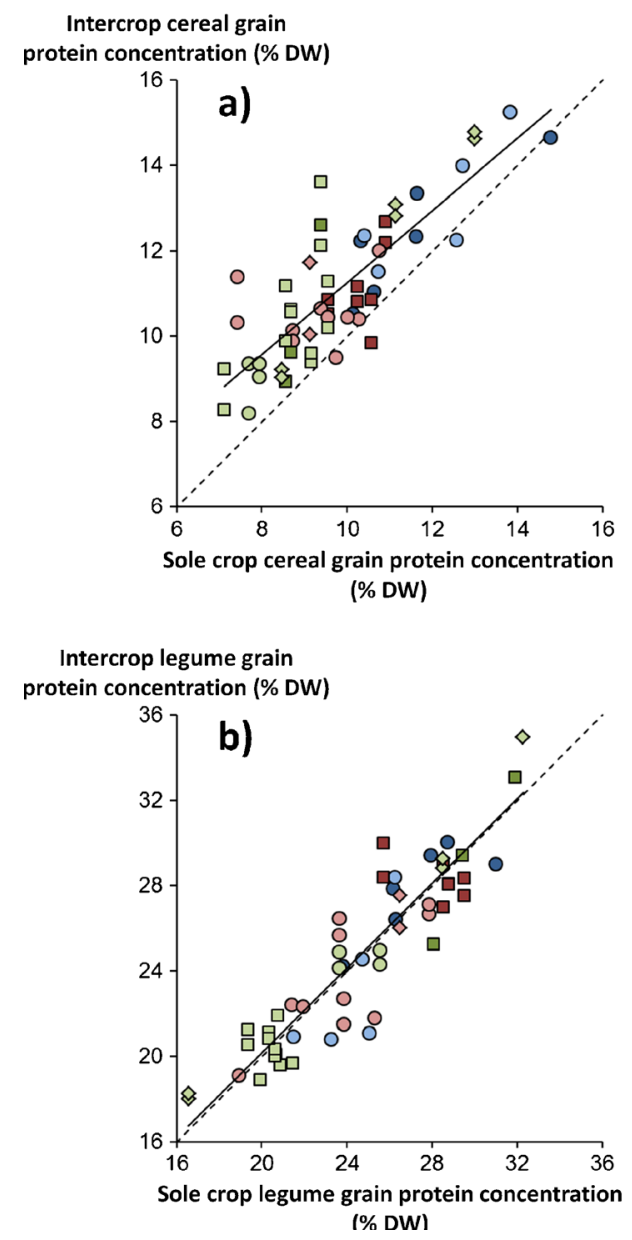

Fig. 7 Grain protein concentration (\% of dry weight; DW) in intercrops as a function of the sole crop grain protein concentration of $\mathbf{a}(y=0.85 x+$ $\left.2.77 ; R^{2}=0.69^{* * *}\right)$ the cereal and $\mathbf{b}\left(y=0.99 x+0.28 ; R^{2}=0.84 * * *\right)$ the legume. The grain protein concentration was calculated by multiplying the nitrogen content by 6.25 for the legume and the barley (animal consumption) and by 5.7 for soft and durum wheat (human consumption). Colour symbols refers to the cereal (red soft wheat, blue hard wheat and green barley). Symbol brightness indicates the legume component (dark faba bean and clear pea). Symbol shape corresponds to the experimental site (circle South of France, diamond West of France and square Denmark). $\mathrm{N}=56$. The results indicate a that the protein concentration of the intercropped cereal is almost always greater than that of the respective sole crop cereal ( $11.1 \%$ versus $9.8 \%$ on average) and the biggest advantage of the intercrop is observed for low grain protein concentration of the sole cropped cereal, thus confirming intercrops benefits in low-nitrogen availability systems. In the case of legumes, $\mathbf{b}$ no difference in average protein concentration could be observed between sole crops and intercrops ( $24.9 \%$ in both cases) certainly due to the ability of the legumes to fulfil their nitrogen requirements mainly by $\mathrm{N}_{2}$ fixation

and more variable in pea sole crops. These results also confirmed that intercropping maintains a highly asymmetric competition over weeds, regardless of the particular species and productivity weed infestation, the crop biomass or the soil nitrogen availability, but these relations must be investigated 


\section{Weeds dry weight at harvest in intercrop and sole crops}
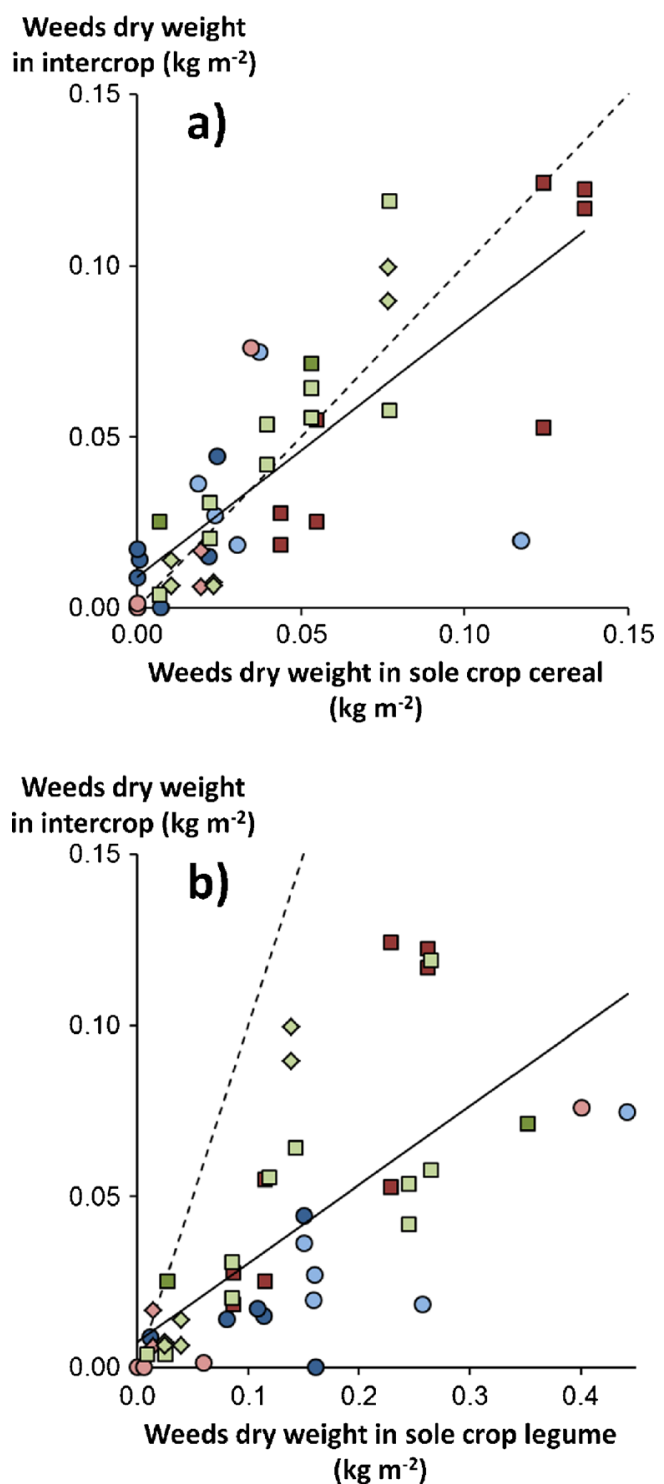

Fig. 8 Weeds dry weight $\left(\mathrm{kg} \mathrm{m}^{-2}\right)$ below intercrops as a function of a $\left(y=0.86 x ; R^{2}=0.59 * * *\right)$ cereal sole crop and $\mathbf{b}\left(y=0.26 x ; R^{2}=0.47^{* * *}\right)$ legume sole crop. Colour symbols refers to the cereal (red soft wheat, blue hard wheat and green: barley). Symbol brightness indicates the legume component (dark faba bean and clear pea). Symbol shape corresponds to the experimental site (circle South of France, diamond West of France and square Denmark). $N=43$. The results show that a weed biomass within the intercrops or the cereal sole crops at harvest are comparable $\left(0.04 \mathrm{~kg} \mathrm{~m}^{-2}\right)$ but b significantly lower than within the legume sole crops $\left(0.14 \mathrm{~kg} \mathrm{~m}^{-2}\right)$. They also confirm that intercropping maintains a highly asymmetric competition over weeds, regardless of the particular species and biomass of weeds, the crop productivity or the soil nitrogen availability

in further details. Moreover, even if intercrops can suppress weeds quite effectively, they could require mechanical weeding, e.g. using tine harrow in some years with heavy infestation. In organic farming, mechanical weeding can be effective when the operation is correctly timed. However, the ideal growth stages for mechanical weeding of the two species in an intercrop can be incompatible and then the time schedule for using mechanical weeding is shorter and more difficult to estimate. Hence, this technique must be applied with care and requires more technical skill as compared to sole cropping.

This weed suppression can be explained by improved resources use efficiency leaving less space, water and nutrients available to the weeds. Nitrogen and light are two main growth levers to reduce weed infestation owing to the intercropped species complementary abilities like: (i) use of nitrogen (soil mineral nitrogen and atmospheric $\mathrm{N}_{2}$ ), (ii) capture of light energy (e.g. Bedoussac and Justes 2010b) and (iii) soil cover (Fig. 9; Anil et al. 1998). These mechanisms for acquisition/interception which are intimately linked and dependent on the temporal and spatial growth dynamics of the shoot and root system (Dreccer et al. 2000) could therefore explain both the intercrop yield gains and weed reduction (Poggio 2005; Banik et al. 2006). It is important to bear in mind that an intercropped cereal is a valuable component to improve competitive ability towards weeds and also providing a physical support to reduce pea lodging. Therefore, intercropping can be a way to successfully produce grain legumes in organic farming and reduce requirement for mechanical weed management.

\section{Partial conclusions from "section 2":}

- Intercropping improved the use of abiotic resources compared to sole cropping, leading to: (i) a higher total grain yield than the mean yield of the respective sole crops in almost all the experiments $(0.33$ versus $0.27 \mathrm{~kg} \mathrm{~m}^{-2}$ ), (ii) a weed biomass reduction compared with the legume sole crops $\left(0.04\right.$ versus $\left.0.14 \mathrm{~kg} \mathrm{~m}^{-2}\right)$ and (iii) a higher protein concentration in grains of the cereal compared to the respective cereal sole crop (11.1 versus $9.8 \%$ ).

- The advantages of the intercrops are higher when the yield of one or both of the respective sole crops is quite low and in case of low grain protein concentration of the sole cropped cereal. It thus confirms intercrops benefits in low-nitrogen availability systems and suggests that intercropping could be a more suitable way to obtain stable yields in organic farming.

\section{Interactions between species and complementary use of $\mathbf{N}$ sources}

3.1 Competition, complementarity and facilitation for use of resources

In multi-species mixtures with two or more species, the interactions between species can be represented as the 
Fig. 9 Durum wheat-winter pea intercrop soil cover dynamics. Pictures of the same spot were taken at various times of the growth period. Sequence to be read from left to right and top to bottom

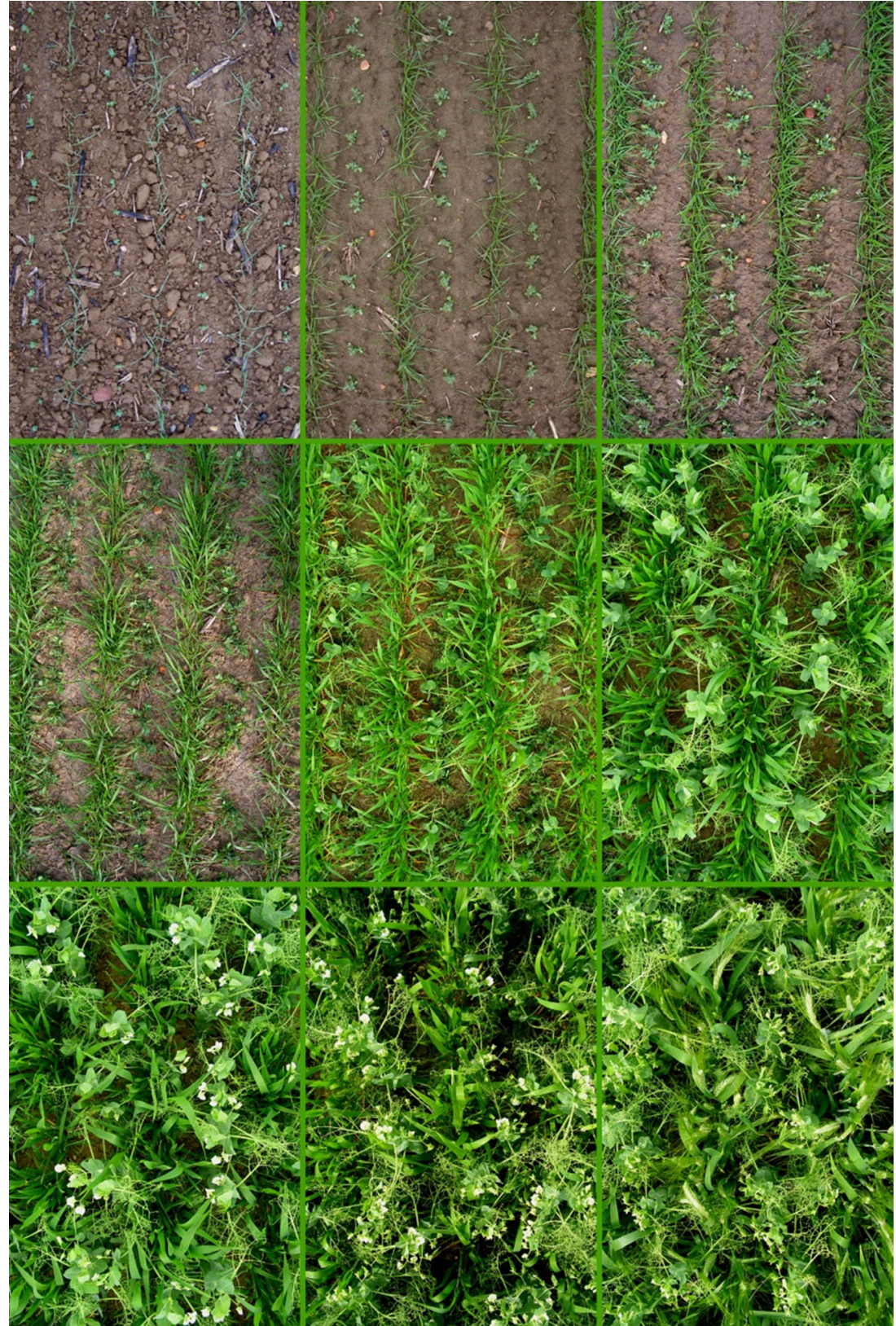

effect of one species on the environment and the response of the other(s) species to this change (Vandermeer 1989; Goldberg 1990). The interactions are complex, occur dynamically over time and space (Connolly et al. 1990) and depend, inter alia, on the availability of nutrients, soil-climatic conditions and the companion species and cultivars. Three types of plant-plant interactions have been distinguished: (i) competition occurring when one species modifies the environment of another adversely, e.g. shading or extraction of a resource which becomes limiting; (ii) complementarity when the intercropped species are not in competition for the same resources in time or space or for a chemical form of a nutrient allowing a more efficient use of environmental resources by the association compared with sole crops (Willey 1979a, 1979b) and then leading to an overall advantage of intercrops such as grain yield, dry weight or grain quality notably when interspecific competitions are less strong than intraspecific competitions and (iii) facilitation when the modification of the environment is beneficial for one component species at least, e.g. allelopathy or the barrier effect against disease spread conferring an advantage to intercrops (Vandermeer 1989; Hauggaard-Nielsen and Jensen 2005), for example, by reducing disease attack (Trenbath 1993), weed competition (Hauggaard-Nielsen et al. 2001b) or by increasing $\mathrm{N}$ transfer and phosphorus availability to cereals (Hinsinger 2001). 
3.2 Intercropping with a non-legume increases the rate of atmospheric $\mathrm{N}_{2}$ fixation but reduces the quantity of nitrogen fixed on an area basis

Among other things, the greater efficiency generally observed in legume/cereal intercrops can be explained by the fact that the two intercropped species use mineral soil $\mathrm{N}$ and atmospheric $\mathrm{N}_{2}$ in a complementary way (Ofori and Stern 1987; Jensen 1996a; Bedoussac and Justes 2010a, 2010b; CorreHellou et al. 2006; Naudin et al. 2010). This is of special interest in organic systems where soil mineral nitrogen can be a limiting factor while cropping legumes as sole crops can be considered as an inefficient way for utilizing the soil $\mathrm{N}$ sources, since the legumes can cover major part of their $\mathrm{N}$ requirements by $\mathrm{N}_{2}$-fixation.

Nevertheless, formation of nodules and their activity in legumes takes place gradually (Tricot et al. 1997; Voisin et al. 2002) and then legumes depend on soil mineral $\mathrm{N}$ and seed $\mathrm{N}$ reserves during early growth (Mahon and Child 1979). Thus, at the beginning of growth, the intercropped cereals and legumes components compete for soil mineral nitrogen via root absorption. Competitive advantage may be determined by differences in the speed of advance of the rooting front (Hamblin and Tennant 1987) and different demands from the beginning of growth (Hauggaard-Nielsen et al. 2001a; Bellostas et al. 2003; Andersen et al. 2004). Hence, in early growth, the sharing of the soil mineral $\mathrm{N}$ will be determined by differences in rooting depth under low soil $\mathrm{N}$ availabilities and by differences in $\mathrm{N}$ demands between species under higher soil $\mathrm{N}$ availabilities (Corre-Hellou et al. 2007).

Consequently, the cereal should be favoured in early stages due to a faster growth and then a greater interspecific competitiveness for soil inorganic $\mathrm{N}$ as compared to the legume (Jensen 1996a). This leads to a rapid decrease in the quantity of available mineral nitrogen in the surface soil layer where occurs symbiotic fixation, which forces the legume to mainly rely on $\mathrm{N}_{2}$-fixation (Hauggaard-Nielsen et al. 2001a). The consequence is a higher percentage of legume nitrogen derived from air compared with sole crops (Jensen 1996a; CorreHellou et al. 2006; Hauggaard-Nielsen et al. 2009b; Naudin et al. 2010), allowing the legume to fulfil its nitrogen requirements (Crozat et al. 1994; Voisin et al. 2002; Naudin et al. 2010). Our analysis, combining the different experiments and growing conditions in organic farming, confirmed a higher percentage of nitrogen derived from air in legumes when intercropped (in average 73 and $61 \%$ of Ndfa for intercrops and sole crops, respectively; Fig. 10a). In that way, almost all available soil $\mathrm{N}$ is utilized by the intercropped cereal component having only this source to fulfil its demand.

However, Naudin et al. (2010) have shown that variations in the availability of mineral nitrogen from about 1.4 to $6.0 \mathrm{~g} \mathrm{~N} \mathrm{~m}^{-2}$ in the $0-30-\mathrm{cm}$ top soil layer occurring before the reproductive stage of peas do not reduce the fixation rate of
Percentage and amount of legume $\mathrm{N}$ derived from air in intercrop and sole crop
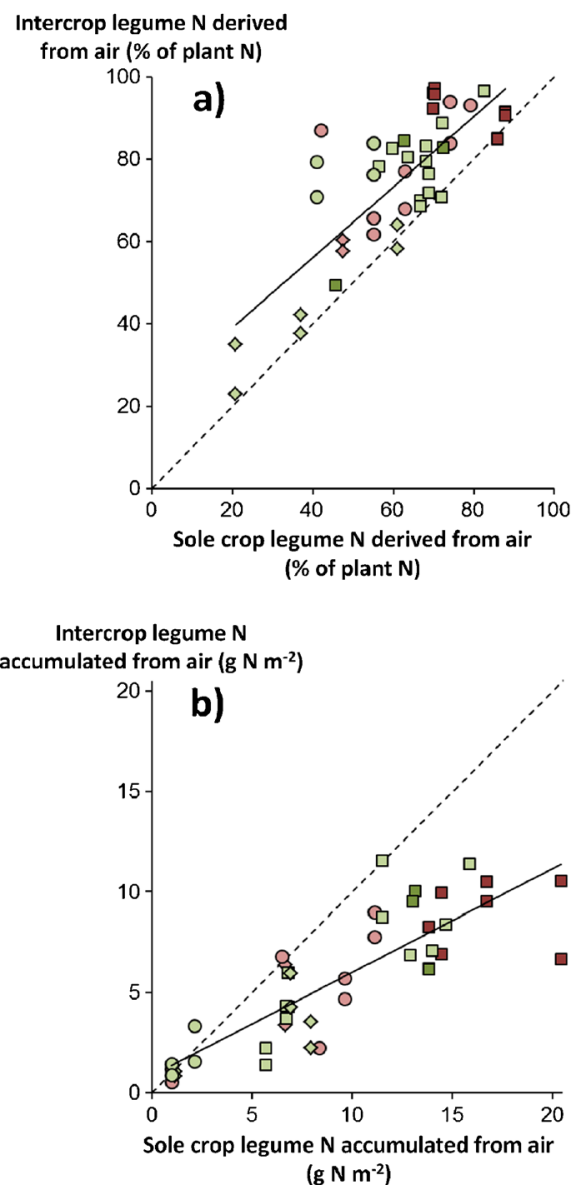

Fig. 10 Percentage of legume plant nitrogen derived from air in intercrop as a function of that in sole crop $\left(\mathbf{a} ; y=0.86 x+22.00 ; R^{2}=0.62 * * *\right)$ and quantity of $\mathrm{N}_{2}$ fixed in shoots $\left(\mathrm{g} \mathrm{N} \mathrm{m}^{-2}\right)$ in intercrop as a function of that in sole crop ( $\left.\mathbf{b} ; y=0.51 x+0.85 ; R^{2}=0.71^{* * *}\right)$. Colour symbols refers to the cereal (red soft wheat, blue hard wheat and green barley). Symbol brightness indicates the legume component (dark faba bean and clear pea). Symbol shape corresponds to the experimental site (circle South of France, diamond West of France and square Denmark). $N=43$. Our analysis, combining the different experiments and growing conditions in organic farming, confirmed a a higher percentage of nitrogen derived from air in legumes when intercropped (in average 73 and $61 \%$ of Ndfa for intercrops and sole crops, respectively). However, the quantity of nitrogen fixed $\mathbf{b}$ by the intercropped legume is less than that of the sole crop legume because of lower biomass compared with the sole crop according to the fewer legume plants per unit area in intercrop altogether with cereal competition for light

intercropped peas. Indeed, in the field experiment carried out in 2007 and 2008 (Naudin et al. 2010), the percentage of legume nitrogen derived from air of intercropped pea in unfertilized treatments increased gradually with thermal time up to $90 \%$ at the end of the crop cycle. The earliest $\mathrm{N}$-supply during vegetative stages of pea, eight leaves entailed a transitory high 
decrease in the percentage of legume nitrogen derived from air. Thereafter, it increased again but remained below the unfertilized intercrop during a main part of the crop cycle. It reached the same value as that observed in unfertilized intercropped peas at maturity. The latest $\mathrm{N}$-supply during pea flowering at the beginning of seed filling entailed a higher decrease in the percentage of legume nitrogen derived from air without a recovery. Soil N-mineral content in 0-30-cm soil layer tended to increase during the few days after $\mathrm{N}$-applications. Then, it remained close to soil N-mineral content observed in nofertilized conditions. The intensity of the transitory inhibition of $\mathrm{N}_{2}$ fixation during the 2 weeks succeeding $\mathrm{N}$-applications is mainly dependent on the nitrates availability. Indeed the percentage of legumes nitrogen derived from air of $\mathrm{N}$-fertilized intercropped peas decreased linearly with soil nitrate content in $0-30$-cm soil layer $\left(y=-1.92 x+103.64 ; R^{2}=0.96^{* *}\right)$. Total inhibition threshold of nitrate content on symbiotic $\mathrm{N}$ fixation could be observed between 3.5 and $5.0 \mathrm{~g}$ nitrate $\mathrm{m}^{-2}$, as previously shown in sole crop by Voisin et al. (2002).

Moreover, since an increase in the early availability of mineral nitrogen tends to favour the biomass of the cereal at the expense of that of the legume, it is often observed that the quantity of nitrogen fixed by the intercropped legume is reduced compared with situations of low-nitrogen availability. Despite the higher symbiotic fixation rate, our data confirmed that the quantity of nitrogen fixed by the intercropped legume is less than that of the sole crop legume (Fig. 10b) because of lower biomass compared with the sole crop according to the fewer legume plants per unit area in intercrop altogether with cereal competition for light (Bedoussac and Justes 2010a). This confirms that differences between intercrops in quantity of nitrogen fixed by legumes are more determined by differences in crop growth than by differences in symbiotic fixation rate (Naudin et al. 2010): in this study, the variability in IC pea biomass whatever $\mathrm{N}$-regimes explained $90 \%$ of the variability in $\mathrm{N}_{2}$ fixation of IC pea $\left(y=0.018 x+1.938 ; R^{2}=0.99^{* * *}\right)$.

\subsection{Complementary use of nitrogen pools}

Because of the soil mineral nitrogen and $\mathrm{N}_{2}$ from the air complementary use between cereals and legumes, intercrops can reduce the risks of nitrate leaching compared to a sole cropped legume (Hauggaard-Nielsen et al. 2003; CorreHellou 2005). Moreover, because intercrops are usually fertilized with a small amount of $\mathrm{N}$, the risks of nitrate leaching are potentially reduced compared to a cereal which has received excessive fertilization (Abad et al. 2004). Soil mineral nitrogen content measured after intercrop harvest which is an indicator of the nitrate leaching risk is $5.1 \pm 3.2 \mathrm{~g} \mathrm{~N} \mathrm{~m}^{-2}$ on average, which is slightly greater than that observed after cereal sole cropping $\left(4.4 \pm 2.8 \mathrm{~g} \mathrm{~N} \mathrm{~m}^{-2}\right.$; Fig. 11a) and on average less than after legume sole cropping (6.0 \pm $3.4 \mathrm{~g} \mathrm{~N} \mathrm{~m}^{-2}$; Fig. 11b). However, because the difference between treatments is relatively small, it is not possible to draw conclusions about reducing nitrate leaching risks using cereal/legume intercropping as compared to legume sole cropping or an excessively fertilized cereal. For such conclusions, it would be necessary to take into account

\section{Soil $\mathbf{N}$ mineral content at harvest in intercrop and sole crops}
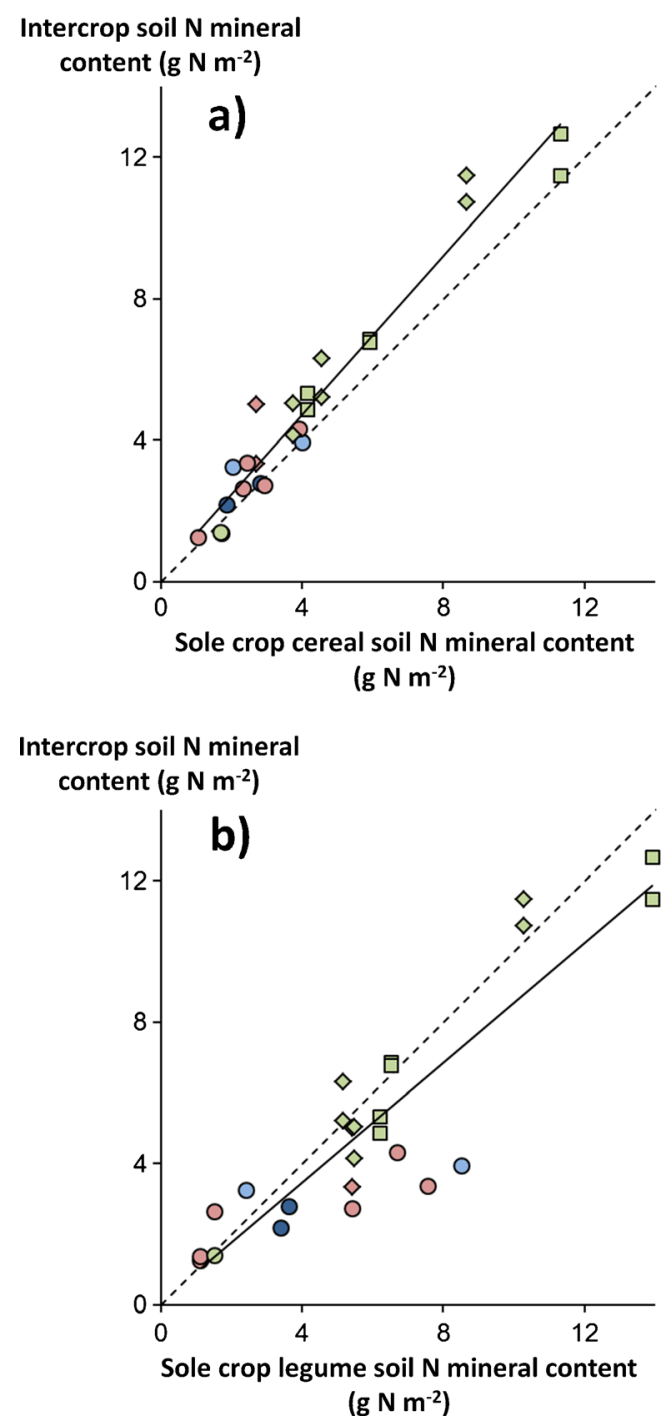

Fig. 11 Soil mineral nitrogen content $\left(\mathrm{g} \mathrm{N} \mathrm{m}^{-2}\right)$ at harvest after cereal/ legume intercropping as a function of $\mathbf{a}\left(y=1.16 x ; R^{2}=0.95^{* * *}\right)$ the cereal sole crop and $\mathbf{b}\left(y=0.86 x ; R^{2}=0.80^{* * *}\right)$ the legume sole crop. Colour symbols refers to the cereal (red soft wheat, blue hard wheat and green barley). Symbol brightness indicates the legume component (dark faba bean and clear pea). Symbol shape corresponds to the experimental site (circle South of France, diamond West of France and square Denmark). $N=25$. Our results indicate that soil mineral nitrogen content measured after intercrop harvest is a slightly greater than that observed after cereal sole crop (5.1 versus $4.4 \mathrm{~g} \mathrm{~N} \mathrm{~m}^{-2}$ on average) and $\mathbf{b}$ less than after legume sole crop $\left(6.0 \mathrm{~g} \mathrm{~N} \mathrm{~m}^{-2}\right)$. However, because the difference between treatments is relatively small it is not possible to draw stabilized conclusions concerning the reduction of nitrate leaching risks with cereal/legume intercropping in comparison to legume sole cropping 
mineralization of roots and crop residues including quantity and chemical characteristics such as carbon/nitrogen ratio which is generally lower for sole crops legumes than for sole crops cereals and intermediate for intercrops together with climatic conditions favouring downwards water movement and practices like the use of catch crop (Justes et al. 2012).

\subsection{Improved light interception}

As already explained, the interactions between intercropped species can occur not only below-ground through soil mineral nitrogen, nutrients and water uptake by the root system but also above-ground through shoot light interception. In the absence of limiting abiotic and biotic factors such as water, nutrients, pests, diseases and weeds, the crop dry matter yield depends mainly on the absorbed radiation (Loomis and Williams 1963) under both the sole crop (Shibles and Weber 1966; Monteith 1977; Kiniry et al. 1989) and the intercrop growing conditions (Natarajan and Willey 1980a, 1980b; Sivakumar and Virmani 1980; 1984). Species differences and interspecific complementarities could allow a better dynamic occupation of the spacewhen crops differ in their shoot architecture - and time - when crop life cycles differs (Trenbath 1986; Tsubo et al. 2001; Tsubo and Walker 2002; Poggio 2005). Then, intercrops could allow an increase in light interception throughout the growth of the intercrop and be more efficient than sole crops for light use (Jahansooz et al. 2007; Bedoussac and Justes 2010b) allowing higher biomass and yield production of the whole intercrop compared to the sole crops.

However, in intercrops, the efficiency of light interception does not only depend on the leaf area ratio and the light extinction coefficient of each species (Sinoquet and Caldwell 1995) which is an empirical parameter related to: (i) the structure of the plant canopy with erect or horizontal leaf habit, (ii) the height of the sun above the horizon and (iii) the diffuse/direct ratio of the radiation. In fact, because of the spatial heterogeneity of the canopy, the distribution of luminous energy depends on the relative values of the intercropped species in terms of height, leaf area and spatial distribution, and species growth dynamics (Fukai 1993; Midmore 1993; Barillot et al. 2014a, 2014b). There is a general agreement that the partition of radiation when intercropping different species is primarily influenced by vertical competition (Spitters and Aerts 1983; Caldwell 1987; Cudney et al. 1991; Cenpukdee and Fukai 1992a, 1992b) and secondly by the crop row orientation and the light extinction coefficient of the leaves of each species.

3.5 Acquisition of nitrogen and light: two intimately linked processes

Nitrogen acquisition and light interception are two intimately linked processes (Dreccer et al. 2000) influenced by the growth dynamics of shoot and root systems. In an intercrop, the leaf structure of cultivated species depends on both the morphogenetic characteristics of each species and the spatial structure of the stand, and the response of each species to the nitrogen status and more generally to their response to inter and intraspecific competition. The nitrogen status - an indicator of the level of fulfilling the crop nitrogen demand (Lemaire and Gastal 1997) - is a determining factor for leaf growth. Consequently, the availability of nitrogen will influence the partition of the radiation by modifying the proportion of each species in the total intercrop leaf area (Gastal and Belanger 1993). Using root and/or shoot compartment techniques Wilson (1988) has shown that root competition is usually dominating shoot competition in the intensity of competition and resource use such as water and nutrients. Competition for soil resources and in particular for nitrogen cannot be studied separately from competition for light. Soil nitrogen supply and plant nitrogen uptake are in permanent interaction with shoot growth (Corre-Hellou et al. 2006) in combination with other environmental conditions like soil water.

\section{Partial conclusions from "section 3":}

- Species differences and interspecific complementarities in their shoot architecture and crop duration cycles could increase light interception throughout the growth of the intercrop allowing higher biomass and yield production compared to the sole crops.

- Intercropped cereals and legumes compete for soil mineral nitrogen in early stages, in favour of the cereal and forcing the legume to increase its $\mathrm{N}_{2}$-fixation in comparison to sole crop (73 versus $61 \%$ of nitrogen derived from air) but decreasing the quantity of nitrogen fixed by the legume due to lower biomass compared with the sole crop according to the half plant density altogether with cereal competition for light in intercrop.

\section{Greatest intercrop advantages in low-input systems}

4.1 The lower the soil nitrogen availability, the greater the intercrop efficiency

Numerous studies suggest that intercrops are particularly suited to low-nitrogen-input systems (Willey 1979a, 1979b; Ofori and Stern 1987; Vandermeer 1989; Willey 1990; Fukai and Trenbath 1993; Jensen 1996a; Hauggaard-Nielsen et al. 2003; Corre-Hellou et al. 2006 and Bedoussac and Justes 2010a, 2010b). For durum wheat/winter pea intercrops (Bedoussac and Justes 2010a), the biggest advantage of the intercrop is observed when the availability of nitrogen during growth is 
low. Conversely, when nitrogen fertilizer is applied, the intercropped legume growth and yield were significantly reduced, while those of wheat increased slightly, leading to a disadvantage of intercrops. This implies that intercropping may be advantageous when nitrogen availability corresponding to soil nitrogen plus $\mathrm{N}$-fertilizer is below a determined threshold ( $12 \mathrm{~g} \mathrm{~N} \mathrm{~m}^{-2}$ in these experiments) due to a high degree of complementary nitrogen use between the two species for low $\mathrm{N}$ levels. Such results have been reported for several cereal/legume intercrops grown in arid, semi-arid, tropical and temperate climates (Fujita et al. 1992; Ofori and Stern 1987; Jensen 1996a; Naudin et al. 2010). Present results confirm that there is a negative correlation between grain yield-based LER and mean yield of the sole crops (Fig. 12) and it is important to emphasize that rather high LER values $(>1.5)$ usually correspond to low yield levels of one or both sole crops, typically the legume.

We also observed a slightly negative correlation (Fig. 13) between grain yield-based LER and soil mineral nitrogen quantities accumulated by the cereal sole crop which is an

\section{Yield land equivalent ratio and sole crops yield}

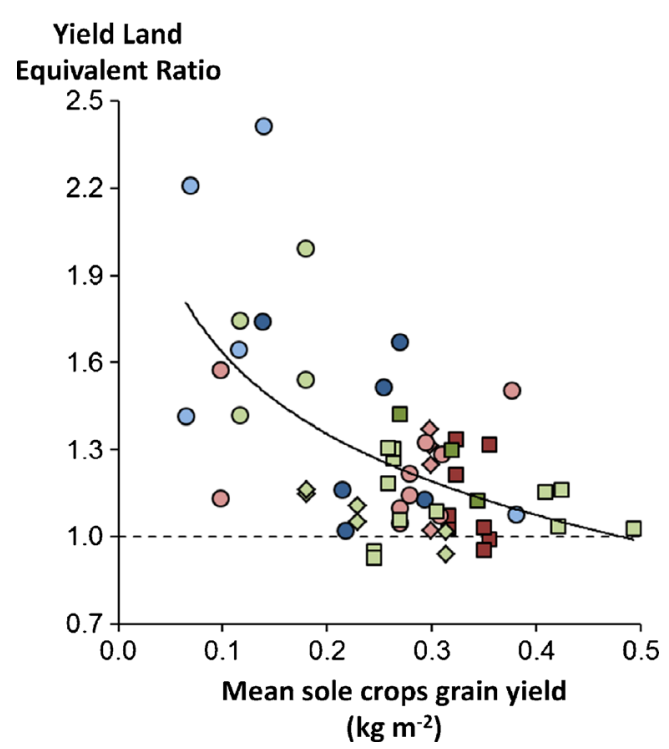

Fig. 12 Land equivalent ratio as a function of mean sole crop (cereal and legume) grain yield $\left(\mathrm{kg} \mathrm{m}^{-2} ; y=0.84 x^{-0.28} ; R^{2}=0.34^{* * *}\right)$. Colour symbols refers to the cereal (red soft wheat, blue hard wheat and green barley). Symbol brightness indicates the legume component (dark faba bean and clear pea). Symbol shape corresponds to the experimental site (circle South of France, diamond West of France and square Denmark). $N=58$. Present results confirm that there is a negative correlation between grain yield-based LER and mean yield of the sole crops. It is also important to emphasize that rather high LER values $(>1.5)$ usually correspond to low yield levels of one or both sole crops, typically the legume. This confirms that intercrops are particularly suited to increase the productivity in low productive conditions and hence some organic farming systems. Therefore, intercropping could be a more suitable way to obtain high and stable yields in such situations

\section{Yield land equivalent ratio and cereal $\mathrm{N}$ accumulated}

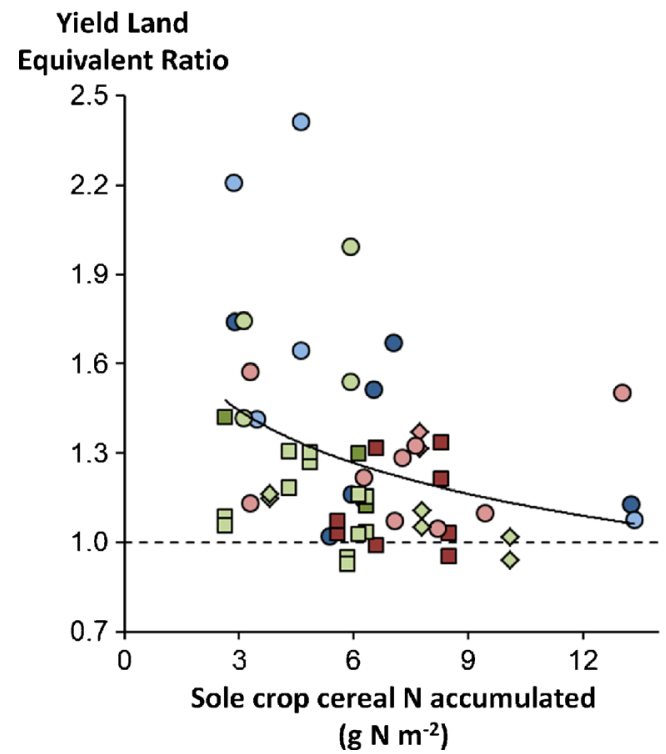

Fig. 13 Land equivalent ratio as a function of nitrogen accumulated in shoots $\left(\mathrm{g} \mathrm{N} \mathrm{m}^{-2} ; y=2.59 x^{-0.18} ; R^{2}=0.12^{* *}\right)$ by the cereal sole crop. Colour symbols refers to the cereal (red soft wheat, blue hard wheat and green barley). Symbol brightness indicates the legume component (dark faba bean and clear pea). Symbol shape corresponds to the experimental site (circle South of France, diamond West of France and square Denmark). $N=56$. Our results demonstrate a slightly negative correlation between grain yield-based LER and soil mineral nitrogen quantities accumulated by the cereal sole crop which is an indicator of the nitrogen availability. This suggests that highest LER values are obtained when competition between plants for soil $\mathrm{N}$ is high, corresponding to a low soil $\mathrm{N}$ availability, and confirms that intercrops are particularly suited to low-nitrogen systems and hence some organic farming systems. Note that in our situations, the range of nitrogen quantities accumulated by the cereal are relatively small, averaging $2.6-$ $13.3 \mathrm{~g} \mathrm{~N} \mathrm{~m}^{-2}$, whereas intensively grown wheat can absorb more than $30 \mathrm{~g} \mathrm{~N} \mathrm{~m}^{-2}$

indicator of the nitrogen availability. In a similar range of soil $\mathrm{N}$ availabilities in spring pea/barley intercrops, the highest LER values were obtained when competition between plants relying on soil $\mathrm{N}$ alone was high corresponding to a low soil $\mathrm{N}$ availability and/or a high plant density of cereal (Corre-Hellou et al. 2006). In our situations, the range of nitrogen quantities accumulated by the cereal are relatively small, averaging 2.6 $13.3 \mathrm{~g} \mathrm{~N} \mathrm{~m}^{-2}$, whereas intensively grown wheat can absorb more than $30 \mathrm{~g} \mathrm{~N} \mathrm{~m}^{-2}$. This could then explain the fact that the correlation with LER is not so significant as that demonstrated by Bedoussac and Justes (2010a) on conventional farming where sole crops cereal accumulated from 7.5 to $20 \mathrm{~g} \mathrm{~N} \mathrm{~m}^{-2}$ according to mineral $\mathrm{N}$ supply.

Finally, the relative advantage of the intercrops ( $\operatorname{LER}_{\text {Yield }}>$ 1) seems to be greater when the yield of the sole crops or the quantity of nitrogen available is low confirming that intercrops are particularly suited to low-nitrogen systems and 
hence some organic farming systems. Moreover, these two relations suggest that in our conditions, intercrop efficiency for grain yield production compared to sole crops depends on $\mathrm{N}$ availability but much more on both biotic and abiotic factors that could have negatively impacted the sole crops grain yield. Finally, due to the numerous treatments in our set of data such as species, sowing proportion and with or without organic $\mathrm{N}$ fertilization it is reasonable to consider that relations between LER and mean sole crops yield or sole crops cereal $\mathrm{N}$ accumulated are not as direct as those observed for a specific kind of intercrop like for conventional durum wheatwinter pea (Bedoussac and Justes 2010a). All in all, intercrop yield advantages occur when intercrop components compete only partly for the same growth resource, possibly influenced by biotic and abiotic interactions, enhancing the complementary effects between species.

4.2 Cereal grain protein concentration in IC depends on sole crop quality, yield reduction and soil mineral use by the legume

The improvement in the protein concentration of the intercropped cereal could be explained by an increase in the quantity of mineral nitrogen available per kilogram of grain

\section{Cereal land equivalent ratio for grain protein and yield}

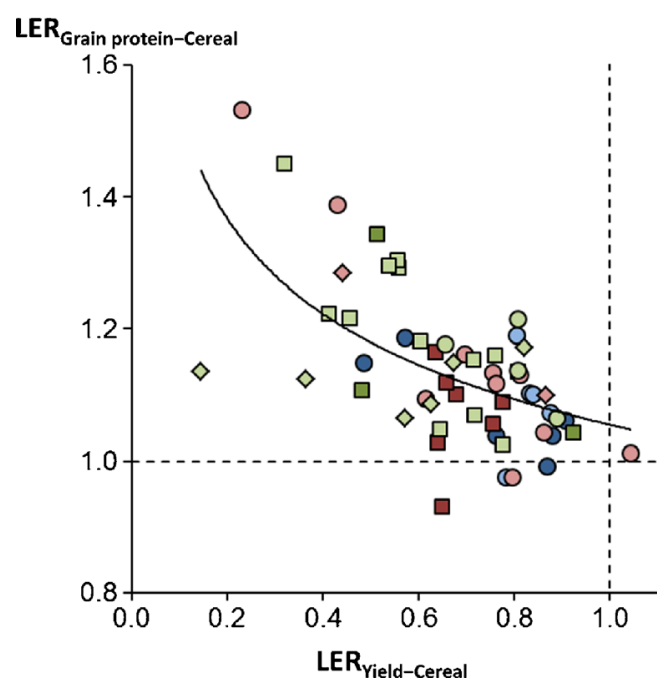

Fig. 14 Cereal partial land equivalent ratio for grain protein concentration as a function of cereal partial land equivalent ratio for grain yield $\left(y=1.06 x^{-0.16} ; R^{2}=0.34^{* * *}\right)$. Colour symbols refers to the cereal (red soft wheat, blue hard wheat and green barley). Symbol brightness indicates the legume component (dark faba bean and clear pea). Symbol shape corresponds to the experimental site (circle South of France, diamond West of France and square Denmark). $N=56$. This figure underlines that the improvement in the protein concentration of the intercropped cereal could be explained primarily by the lower grain production of the intercropped cereal compared with the sole crop situation ( 0.19 and $0.29 \mathrm{~kg} \mathrm{~m}^{-2}$, respectively) which is found in $98 \%$ of our experiments produced and/or by a better fit between nitrogen requirements of the cereal and soil mineral nitrogen availability. The first hypothesis is explained primarily by the lower grain production of the intercropped cereal compared with the sole crop situation ( 0.19 and $0.29 \mathrm{~kg} \mathrm{~m}^{-2}$, respectively) which is found in most cases ( $98 \%$ of our experiments) (Fig. 14). Nevertheless, Bedoussac (2009) showed that intercropped cereal protein concentration is strongly correlated with that in the sole crop representing genotype's response to environmental conditions. Actually, one can estimate the protein concentration of the intercropped cereal quite well from the protein concentration of the sole cropped cereal and the grain yield-based partial cereal land equivalent ratio which is indeed the yield loss compared with the sole crop (Fig. 15).

Gooding et al. (2007) confirmed by Bedoussac and Justes (2010a, 2010b) explained that the intercropping effect on grain protein concentration of wheat was due to a higher soil $\mathrm{N}$ availability for the cereal on a per plant or a per grain basis in intercrop in comparison with sole crops. It was shown to be the result of: (i) the low competitiveness of legumes for mineral $\mathrm{N}$ compared with cereals, combined with (ii) competition for light, water and other nutrients, between the two species, which lead to limit intercropped cereal biomass and

\section{Estimation of cereal grain protein concentration}

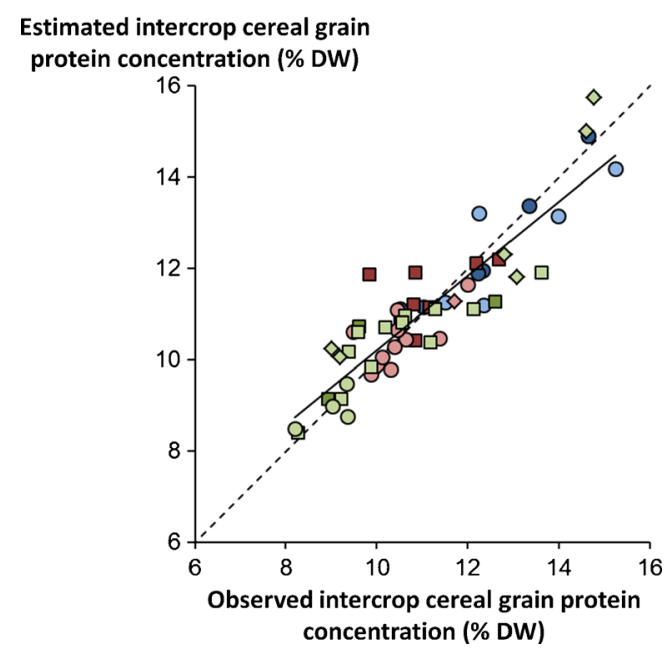

Fig. 15 Estimated intercropped cereal grain protein concentration (GPC) as a function of observed values $\left(y=0.82 x+2.05 ; R^{2}=0.82 * * *\right)$ considering the linear model: $\mathrm{GPC}_{\text {Cereal-Intercrop }}=a \times \mathrm{GPC}_{\text {Cereal-Sole crop }}+$ $b \times \mathrm{LER}_{\text {Yield-Cereal }}+c$ with $a=0.90, b=-3.35, c=4.56, \mathrm{RMSE}=0.73 \%$ and bias $=0.00 \%$. Colour symbols refers to the cereal (red soft wheat, blue hard wheat and green barley). Symbol brightness indicates the legume component (dark faba bean and clear pea). Symbol shape corresponds to the experimental site (circle South of France, diamond West of France and square Denmark). $N=56$. This figure shows that one can estimate the protein concentration of the intercropped cereal quite well from both the protein concentration of the sole cropped cereal representing the genotype response to environmental conditions and the grain yield-based partial cereal land equivalent ratio which is indeed the yield loss compared with the sole crop 
yield. Indeed, a reduced yield of the cereal in intercrop compared to the sole crop can lead to an increase in the quantity of available nitrogen per kilogram of grain produced by the intercropped cereal only if the total quantity of available nitrogen is not reduced by the intercropped legume $\mathrm{N}$ uptake in the same proportion as the cereal yield. In fact, from a simplified theoretical scheme, one can demonstrate that the quantity of available nitrogen per kilogram of grain for the intercropped cereal $\left(\mathrm{Nmin}_{\text {Cereal-Intercrop }} /\right.$ Yield $\left._{\text {Cereal-Intercrop }}\right)$ is greater than that of the pure cereal $\left(\mathrm{Nmin}_{\text {Cereal-Sole crop }} /\right.$ Yield ${ }_{\text {Cereal-Sole crop }}$ ) is equivalent to:

$\operatorname{Nmin}_{\text {Cereal-Sole crop }} \times\left(1-\frac{\text { Yield }_{\text {Cereal-Intercrop }}}{\text { Yield }_{\text {Cereal-Sole crop }}}\right)$

$>$ Ndfsoil $_{\text {Legume-Intercrop }}$

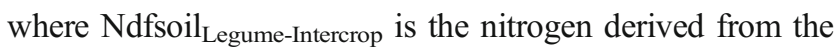
soil accumulated in the shoots of the intercropped legume. On average for all the available data $(N=58)$, we find Yield $_{\text {Cereal-Sole crop }}=0.29 \mathrm{~kg} \mathrm{~m}^{-2}$ and Yield Cereal-Intercrop $=$ $0.20 \mathrm{~kg} \mathrm{~m}^{-2}$ and the total available nitrogen can be estimated on average to $10.7 \mathrm{~g} \mathrm{~N} \mathrm{~m}^{-2}\left(6.3 \mathrm{~g} \mathrm{~N} \mathrm{~m}^{-2}\right.$ accumulated by the sole crops cereal to which is added $4.4 \mathrm{~g} \mathrm{~N} \mathrm{~m}^{-2}$ of the nitrogen residue at harvest on average). Then:

$$
\begin{aligned}
& \operatorname{Nmin}_{\text {Cereal-Sole crop }} \times\left(1-\frac{\text { Yield }_{\text {Cereal-Intercrop }}}{\text { Yield }_{\text {Cereal-Sole crop }}}\right) \\
& =10.7 \times\left(1-\frac{0.20}{0.29}\right) \approx 3.3 \mathrm{~g} \mathrm{Nm}^{-2}
\end{aligned}
$$

Consequently, considering all our experiments, the quantity of nitrogen available per kilogram of grain for the associated cereal will be greater than that of the sole cropped cereal if the nitrogen accumulated in the shoots of the intercropped legume coming from the soil is less than $3.3 \mathrm{~g} \mathrm{~N} \mathrm{~m}^{-2}$ which is the case in our experiments. Indeed, $27 \%$ of the nitrogen accumulated in the shoots of the intercropped legume came from the soil (Fig. 10a) representing on average only $1.9 \mathrm{~g} \mathrm{~N} \mathrm{~m}^{-2}$.

However, this might only be part of the explanation. Several authors, using ${ }^{15} \mathrm{~N}$ labelling methods and root compartment techniques (e.g. Khan et al. 2002a, 2002b; Mayer et al. 2003), have shown the effects of the legume on facilitating the acquisition of nitrogen by the cereal (Stern 1993; Jensen 1996b; Xiao et al. 2004; Chalk et al. 2014) and the transfer of nitrogen from the legume to the cereal. These exchanges are explained by the production by the legume roots of relatively labile nitrogen-rich exudates in the form of $\mathrm{NH}_{4}{ }^{+}$(Brophy and Heichel 1989), $\mathrm{NO}_{3}{ }^{-}$(Wacquant et al. 1989), amino acids (Paynel et al. 2001, 2008; Lesuffleur et al. 2013) or decomposing plant parts (Johansen and Jensen 1996; Fustec et al. 2010).
These root deposits can represent up to $30 \%$ of the $\mathrm{N}$ plant for a field pea (Mahieu 2007). A part of these root deposits can be used by the associated cereal or by the legume itself either directly or after bio-transformation by the soil microbial biomass (Fustec et al. 2010) and can contribute up to $50 \%$ of the nitrogen absorbed by the graminaceous in perennial intercrops of ryegrass and white clover (Hogh-Jensen and Schjoerring 2001). Conversely, in annual barley/peas intercrops, these transfers represent only up to $19 \%$ (Jensen 1996b) because legume root deposits are not totally mineralized during the $\mathrm{N}$ acquisition by the cereal. The amount of $\mathrm{N}$ exchanged between plants is higher when soil mineral $\mathrm{N}$ is low and when roots are intermingled (Jensen 1996a; Xiao et al. 2004; Fustec et al. 2014). In addition, within the growth time of annual intercrops, net transfer from the legume to the companion crop has been found negligible because of the amount of $\mathrm{N}$ transferred from the companion crop to the legume (Jamont et al. 2013; Fustec et al. 2014). Finally, while legume root deposits may be a significant source of $\mathrm{N}$ to intercropped cereal at low rates of $\mathrm{N}$-fertilization, they are regarded as small in high fertilized systems including organic farming in view of the high total quantity of nitrogen available.

The second hypothesis, which does not exclude the first, is based upon a better fit of the nitrogen availability to the cereal requirements depending on the developmental stage and the yield level. Consequently, only a change in the availability of nitrogen at a stage when the crop requirements are high could reduce the nitrogen deficiency of the intercropped cereal as compared with the sole crop and thus improve its quality and relative yield. This support the previous explanation that the effect of intercropping is small or absent when large soil mineral $\mathrm{N}$ is available. Again, intercropping shows its greatest potentials in systems with low nitrogen availability, where the equilibrium between fixation and absorption of soil mineral nitrogen by the two species allows an adjustment of the availability to the needs (Fujita et al. 1992; Tofinga et al. 1993; Hauggaard-Nielsen et al. 2001a, 2001b; Corre-Hellou et al. 2006; Naudin et al. 2010; Hauggaard-Nielsen et al. 2003).

In general, it can be difficult to specifically increase the protein content of, for example, wheat grown as sole crop with high rates of top-dressed applications of fertilizer N. Increased applications of $\mathrm{N}$ will often result in a greater accumulation of dry matter and the increased $\mathrm{N}$ uptake may mostly be 'diluted' in enhanced vegetative biomass and grain yield without necessarily being translated into improved grain protein content (Lemaire and Gastal 1997). Thus, in cereal-legume intercrops, the increased $\mathrm{N}$ availability for the cereal in conjunction with the competition with the legume for factors such as light and water are likely to result in a relatively larger increase in wheat protein content than dry matter production. In that way, such intra- and inter-plant competitive interactions induce physiological responses in the component crops which have the potential to change grain quality parameters. 


\section{Partial conclusions from 'section 4':}

- LER is negatively correlated both with mean yield of the sole crops and soil mineral nitrogen availability, confirming that intercrops are particularly suited to low-nitrogen-input systems and could be a more suitable way to obtain high and stable yields in such situations.

- The improvement in the protein concentration of cereal in intercrop is the result of: (i) the low competitiveness of legumes for mineral $\mathrm{N}$ combined with (ii) the lower intercropped cereal yield compared with the sole crop (0.19 and $0.29 \mathrm{~kg} \mathrm{~m}^{-2}$, respectively).

\section{Designing appropriate crop management systems and crop rotations}

\subsection{General principles}

Designing crop management systems - the logical and sequentially arranged techniques applied on a farm field to achieve a given production objective (Sebillotte 1974) - is much the same for intercrops and sole crops except that the choices have to be made for several crops instead of just one. The choices of species, varieties, plant densities and patterns, and nitrogen fertilization levels are regarded as the determining factors of the performance and functioning of intercrops. Interactions between these various factors in relation to the production objective make generalizations rather difficult. However, two general rules can be defined as follows: (i) improve use of light energy and (ii) improve use of nitrogen sources. As mentioned earlier, interspecific interactions are in most cases controlled by the spatial and temporal complementarity between the intercropped components - especially soil mineral $\mathrm{N}$ acquisition by the cereal and atmospheric $\mathrm{N}_{2}$ fixation by the legume. With respect to light, the dominant species should have a shoot architecture and biomass production which allows a reasonable amount of light below its canopy, which boils down to the choice of species, varieties and nitrogen availability (Berntsen et al. 2004; Jahansooz et al. 2007). In most situations, the cereal is the dominant species based on biomass production because of its earliness, its height relative to that of the legumes and its ability to produce tillers. The opposite can also be true like for durum wheat/ winter faba bean intercrops (Bedoussac 2009). Consequently, one would favour a short-strawed hard wheat variety to intercrop with short or low competitive legumes and a longstrawed one for mixtures with tall legumes like faba beans. Moreover, with the objective of improving the protein concentration for the cereal, one would look for a cereal variety with good sole crop technological characteristics such as grain protein concentration or vitreousness, but at the same time with sufficient sensitivity to legume interspecific competition to reduce its yield.

It is important to notice that most selection programmes are based on sole cropping systems which are quite intensive in terms of synthetic inputs (Davis and Woolley 1993; Nelson and Robichaux 1997; O'Leary and Smith 1999) and these same varieties are often used in intercrops. However, Carr et al. (1998) have shown that the forage yields of barley/peas or oats/peas intercrops were higher when the varieties of cereals used had been selected in multi-species stands rather than in intraspecific mixtures using varieties arising from selection in sole crop stands. Thus, the identification of the species and varietal traits suited to intercropping and more generally for low-input systems and organic farming is therefore an important issue and will necessitate reviewing the varietal selection criteria: those used for sole crops are probably not ideal for intercrops and especially for organic farming systems.

\subsection{Designing crop management according to production} objectives

Adoption of intercropping strategies might be motivated by several production objectives. As discussed by Naudin et al. (2010), one might wish to improve the quality of the cereal by maximizing the availability of soil mineral nitrogen for the cereal by increasing the symbiotic fixation rate of the legume. To do this, one would favour an early-developing cereal to rapidly deplete the mineral nitrogen pool available to the legume. For the legume, one would choose species and varieties with a root development able to cover its early nitrogen needs, including an early start of $\mathrm{N}_{2}$ fixation. In other situations, the objective could be to use intercrops for producing legumes, which is a major issue in Europe where $70 \%$ of the plant protein requirements are imported (2011-2012 data, PROLEA 2013) and particularly important in organic farming, both to satisfy requirements for human food and to manufacture balanced animal feeds. Moreover, it is sometimes difficult to obtain satisfactory yields in organic farming, notably in the case of winter peas because of: (i) their inability to compete with weeds; (ii) diseases such as pea blight which cause lodging at maturity, hindering harvest, and (iii) pests such as aphids and pea weevils. In this case, one would choose high legume densities close to those of sole cropping and lower densities for companion cereal altogether with the absence of $\mathrm{N}$ fertilization. The main role for the cereal in such intercrop is to reduce weed pressure and the spread of diseases and pests by the physical barrier effect and, in the case of peas, to provide mechanical support to avoid lodging. However, intercrops evaluation should not only be considered in terms of crop management practices but also include the pluriannual cropping system. Issues such as integration of 
intercrops within traditional rotations and their subsequent crop effects, minimum time of return between two intercrops need to be clarified. For instance if the intercrops can significantly reduce the pest and disease pressure, it may be possible to shorten the return times compared with sole crops, though probably not drastically. It is also reasonable to imagine the succession of different cereal/grain legume intercrops, whose possible combinations are numerous, and for the more southerly climates of Europe to consider summer crops, e.g. sunflower/soya.

\subsection{Densities, spatial structure and nitrogen fertilization}

In the case of pure stands, the response to plant density is generally well known, but this is not the case for intercrops. Most authors carry out experiments by sowing each species at a density half of that of the sole crops in a replacement design. However, as it has been shown for maize/bean (Phaseolus vulgaris L.) mixtures (Willey and Osiru 1972 and others), the optimal total density in the intercrops can be greater than that of each of the pure crops because of the complementarity between species. Higher plant density increases the competition between the components of the mixture which, as Willey (1979a) noted, tends to favour the dominant species. For example, Hauggaard-Nielsen et al. (2006) observed that at low and recommended density the proportions of pea and barley in the final grain yield was not markedly different from the expected proportions sown while at high density, the suppression of barley strongly increased the proportion of pea in the final grain yield. Consequently, one would favour - compared with a sowing density of $50 \%$ of that in sole cropping - an increase in the density of the dominated species and/or a reduction of that of the dominant species in additive design. For example, Bedoussac (2009) has shown that in mixtures with durum wheat, the density of peas could be the same as that of the pure crop, whereas that of faba beans should be fairly low if one wishes to have a proportion of cereal grain in the intercrop of about $50 \%$.

Apart from species, varieties and densities, the spatial structure of intercrops, e.g. mixtures within the row or as alternate rows or strips of varying width, do modify the distribution of radiation, water and nutrients. In the case of maize/pigeon pea (Cajanus cajan L.) mixtures, Dalal (1974) showed that the yield of maize was reduced when both species were mixed within the same row compared with being grown in alternate rows. Mohta and De (1980) showed for maize/ soya and sorghum/soya mixtures that the maize and sorghum yields were similar for $1 \times 1(1$ row $\times 1$ row $)$ and $2 \times 2$ intercrops, whereas the soya yield was higher in the $2 \times 2$ situations. Chen et al. (2003) showed for barley/pea intercrops that the yield of the peas in $4 \times 4$ mixtures was higher than that in $2 \times 2$ mixtures and higher than in mixtures within the row. The converse applied to the barley. Consequently, densities should be chosen according to the spatial arrangement of the species and vice versa, depending on the production objectives.

Complementarity between intercropped cereals and legumes strongly depends on the availability of nitrogen and thus on organic nitrogen fertilization. In fact, high $\mathrm{N}$ availability tends to reduce the yield of the legume to the benefit of the cereal as shown on various intercrop mixtures (Hauggaard-Nielsen and Jensen 2001; Bedoussac and Justes 2010a; Naudin et al. 2010). From a dynamic point of view, increased availability of nitrogen in early growth stages will result in: (i) reduced amount of nitrogen fixed, (ii) reduced legume yield and (iii) a corresponding increased cereal yield. Naudin et al. (2010) showed that mineral N fertilization applied after the beginning of pea flowering stops its symbiotic fixation activity compared to the unfertilized treatment. Then, late availability of nitrogen will have little or no effect on the nitrogen nutrition of the legume and then on its yield but will improve the protein concentration of the cereal. However, unlike mineral nitrogen which is immediately available, organic manures such as animal manure or green manuring undergo mineralization meaning that in organic farming, one has to manage nitrogen fertilization from manure by including the dynamics of mineralization. Consequently, for organic manures characterized by slow dynamics of $\mathrm{N}$-mineralization, e.g. cattle or green manure with high carbon/nitrogen ratio, only early applications can have an effect on the behaviour of the intercrop and in particular on the proportion of the two species at harvest.

\section{Partial conclusions from 'section 5':}

- The adoption of intercropping strategies might be motivated by several production objectives; nevertheless, the choices of species, varieties, plant densities or nitrogen fertilization levels determine greatly the performance of intercrops that make generalization of optimized combinations rather difficult.

- In most situations, the cereal is the dominant species based on biomass production because of its earliness for initial growth; this advantage is increased by high-N availability and it is then recommended to limit nitrogen supply at early stages to improve balanced complementarity between intercropped cereals and legumes.

\section{Economic benefits and variability of intercropping}

Crop rotation, soil fertility, nitrate levels, quality requirements that crops may have to meet in animal fodder and/or human food are factors influencing crop preference by farmers. Furthermore, farmers are increasingly prone to fluctuating 
commodity prices depending on the availability of a market which makes the cropping system management difficult. In particular, the potential economic advantage of intercrops depends on the selling prices of the crops and on the differential between cereal and legume, which is a difficult figure to obtain when prices are volatile. In general, we observe that the sale price of organic grain legumes is higher than that of standard-quality wheat and comparable with that of highquality wheat. From our data, we calculated the gross product of sole crops and intercrops considering selling prices of $260 €$ $\mathrm{Mg}^{-1}$ for hard wheat, $270 € \mathrm{Mg}^{-1}$ for soft wheat, $240 € \mathrm{Mg}^{-1}$ for barley, $350 € \mathrm{Mg}^{-1}$ for faba bean and $350 € \mathrm{Mg}^{-1}$ for pea.

We also integrated a premium depending on the quality of the intercropped cereal in order to take into account the greater economic value of cereal grains according to higher grain protein concentration. As an example, the selling price of hard wheat increased by $90 € \mathrm{Mg}^{-1}$ when the grain protein concentration is higher than $13.5 \%$ for a basic price of $260 € \mathrm{Mg}^{-1}$. This large gain was also and largely due to the nonvitreousness content which was invariably below $25 \%$, a threshold required by the processors of grain into semolina and pastries. Similarly, the selling price of soft wheat increased by $60 € \mathrm{Mg}^{-1}$ when the grain protein concentration is higher than $11.5 \%$ for a basic price of $270 € \mathrm{Mg}^{-1}$. Focusing on soft wheat/faba bean intercrops, Gooding et al. (2007) included sites and seasons for five different regions across Europe and showed that increases in crude protein concentration in the wheat of $10 \mathrm{~g} \mathrm{~kg}^{-1}$ associated with $25-30 \%$ yield reduction of the wheat in IC could be of economic benefit when selling wheat for bread making, but only if the bean crop is also effectively marketed (Gooding et al. 2007).

We finally considered the following costs to calculate the gross margin: (i) $40 € \mathrm{ha}^{-1}$ for sowing $\left(80 € \mathrm{ha}^{-1}\right.$ for IC with faba bean because of a second pass), (ii) $100 € \mathrm{ha}^{-1}$ for seeds in all treatments and proportionally higher for IC with a relative density greater than one, (iii) $80 € \mathrm{ha}^{-1}$ for harvest and (iv) $30 €$ $\mathrm{Mg}^{-1}$ for intercropping sorting out except for IC with barley considering a direct commercialization for animal feeding. No fertilization cost was integrated considering that fertilized treatments manure was produced on the farm.

From the micro-economic point of view, there is an economic advantage of intercropping in organic farming due to the increase in total grain yields in intercrops as compared to the respective sole crops even if this advantage could be modulated according to the relative prices of the two crops. On average, the whole IC gross margin was higher than that of the mean sole crops (702 versus $577 €$ $\mathrm{ha}^{-1}$; Fig. 16a) and this advantage was found in $80 \%$ of the treatments. This advantage is also observed (in $71 \%$ of the treatments) when comparing to the cereal sole crops gross margin (520€ $\mathrm{ha}^{-1}$; Fig. 16b) and in $70 \%$ of the treatments when comparing to the legume sole crops (634€ha ${ }^{-1}$; Fig. 16c). It is important to notice that the advantage is increased for years where one of sole crops had low yields like, e.g. in 2009 , for winter peas $\left(0.05 \mathrm{~kg} \mathrm{~m}^{-2}\right.$ on average). Our data underlined that the variability in gross margin is lower for the intercrops than for the sole crops legume (standard deviation of $335 € \mathrm{ha}^{-1}$ compared to $493 € \mathrm{ha}^{-1}$ ) but higher than that of the sole crops cereal $\left(246 € \mathrm{ha}^{-1}\right)$ and slightly higher than that of the mean sole crops $(302 €$ $\mathrm{ha}^{-1}$ ). Then, while intercropping might in some years perform an intermediate net income for the farmer compared to the sole crops, it is regarded as a better safeguard. Particularly, this is remarkable when comparing the intercrop gross margin with that of the grain legume sole cropping which are instable and then less favoured in organic crop rotations.

However, after combined harvesting, the intercropped crops need to be sorted correctly. In fact, the effectiveness of the sorting of the grains from the intercrop will determine whether the harvest can be sold for direct human consumption and thus at a potentially higher price than for animal consumption. The main obstacle to the development of intercrops for the companies collecting and storing seeds is their capacity for sorting large volumes efficiently, quickly and cheaply. This practical question thus poses various difficulties not only in terms of choice of machinery and its adjustment but also from the logistic point of view of the companies collecting and storing seeds. Indeed, their organizational structure can play the role of a self-reinforcement mechanism that reduces the incentives to adopt new practices (Fares et al. 2012). From the purely technical point of view, it seems possible to correctly separate the grains of the two species provided that they differ in size and shape and/or to accept having an inseparable fraction of legume-cereal grains. It is also important to ensure that the mixture does not contain too many broken grains, which depends on harvesting conditions and adjustments of the combine harvester. Hence, when growing intercrops, it is preferable to use species and varieties having similar maturity dates and combine harvester adjustments suitable for the more fragile species such as gentle threshing and/or using an axial combine harvester at the risk of losing some grain of the other species altogether with a cereal easy to thresh. Using intercropping on farm to produce animal feed seems less problematic as it is possible either to sort the grain crudely or else to correct the diet by adding to the harvested mixture one or other of the two species.

\section{Partial conclusions from 'section 6':}

- The effectiveness of the grain sorting after harvest will determine whether the grain from intercrop can be sold at a potentially high price; this then represents the main obstacle to the development of intercrops for the companies collecting and storing seeds in terms of 
Total intercrop gross margin compared to that of sole crops

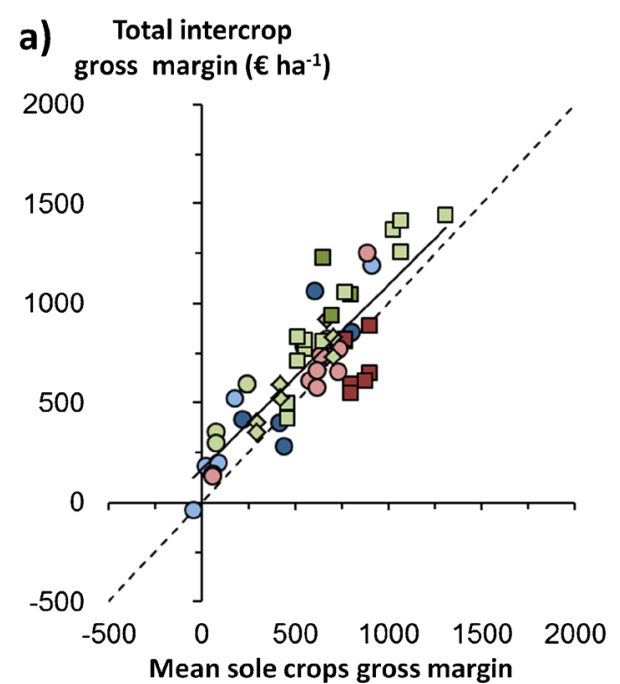

$\left(€ \mathrm{ha}^{-1}\right.$ )

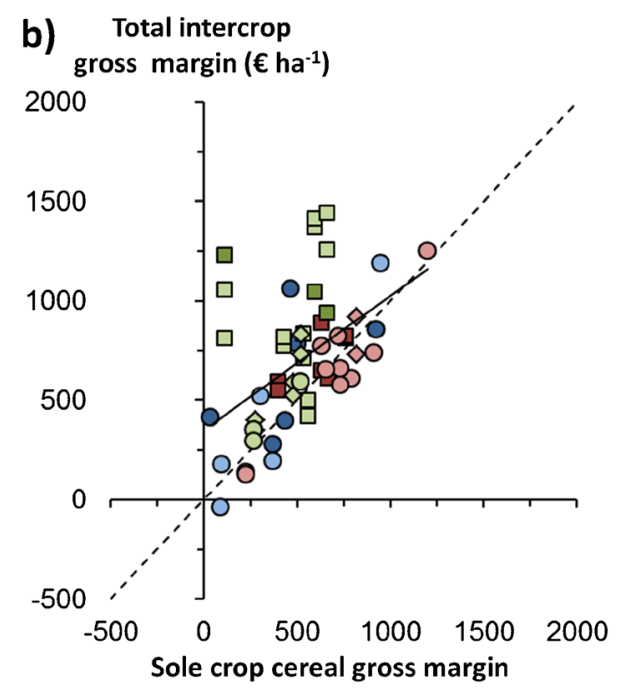

$\left(€\right.$ ha $\left.^{-1}\right)$

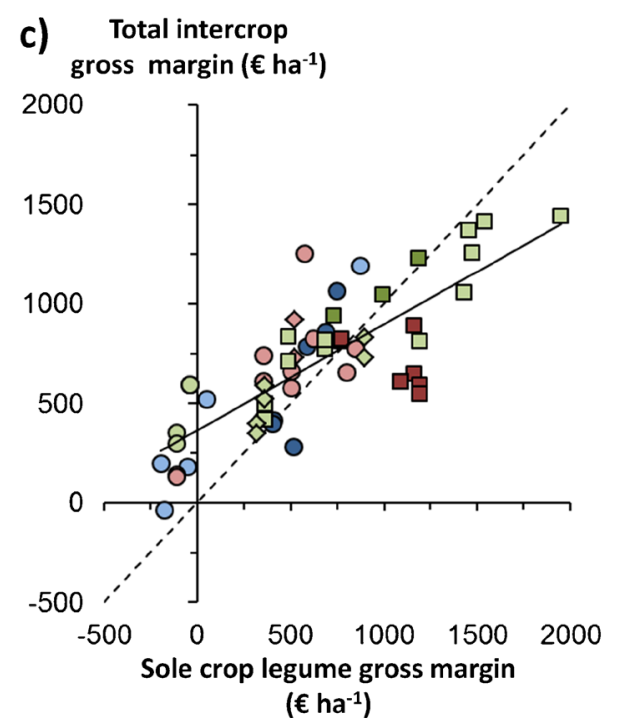

Fig. 16 Intercrop (IC) gross margin (considering a premium on IC cereal price proportional to the ratio between grain protein concentration in intercrop and sole crop, an additive seeds cost for intercrops with relative density higher than one, a second sowing pass cost for intercrops with faba bean and a sorting out cost except for intercrops with barley) as a function of $\mathbf{a}\left(y=0.93 x+166.12 ; R^{2}=0.70 * * *\right)$ mean sole crops gross margin, $\mathbf{b}\left(y=0.68 x+350.09 ; R^{2}=0.25^{* * *}\right)$ sole crop cereal gross margin and $\mathbf{c}\left(y=0.53 x+365.83 ; R^{2}=0.61 * * *\right)$ sole crop legume gross margin. Colour symbols refers to the cereal (red soft wheat, blue hard wheat and green barley). Symbol brightness indicates the legume component (dark faba bean and clear pea). Symbol shape corresponds to the experimental site (circle South of France, diamond West of France and square Denmark). $N=56$. Note that on average, the whole IC gross margin was a higher than that of the mean sole crops in $80 \%$ of the treatments (702 versus $577 € \mathrm{ha}^{-1}$ ) and this advantage is also observed in $70 \%$ of the treatments when comparing to b the cereal sole crops $(520 €$ $\mathrm{ha}^{-1}$ ) or $\mathbf{c}$ the legume sole crops $\left(634 € \mathrm{ha}^{-1}\right)$. It is also important to notice that while intercropping might in some years perform with an intermediate net income for the farmer compared to the sole crops, it is regarded as a better safeguard. Thus, the advantage is particularly increased for years where one of sole crops had low yields and the advantage is remarkable when comparing the intercrop gross margin with that of the grain legume sole crops which are instable and then less favoured in organic crop rotations

machinery and logistic.

- Considering the hypothesis that grain from intercrops can be sorted, its gross margin is higher than that of the mean sole crops in $80 \%$ of our treatments (702 versus $577 € \mathrm{ha}^{-1}$ ); thus, intercropping might be regarded as a better safeguard particularly for years where one of sole crops has low yields.

\section{Conclusion and perspectives}

We have shown that intercrops present numerous advantages and appear to be a useful agronomic solution for arable cropping. However, it is difficult to propose fundamentally based and generic crop technical strategies because of the multitude of possible production objectives and hence of combinations of species, varieties, densities, structure and organic manure strategies. This shows the limitations of experiments and the value of modelling multi-species cropping systems (Brisson et al. 2004; Corre-Hellou et al. 2009; Launay et al. 2009). In fact, for a given production objective, modelling would allow the following: (i) the performance and behaviour of intercrops to be evaluated under a wide range of conditions, (ii) to help with the determination of varietal characteristics suited to intercropping (Barillot et al. 2012, 2014a, 2014b), (iii) to optimize the crop technical protocols according to multiple criteria and (iv) to devise a decision-aid model. However, this requires further mechanistic understanding of the behaviour of multi-species cropping systems and to integrate this knowledge into current crop models or to develop new ones to correctly represent the inter and intraspecific 
competition (Launay et al. 2009). Such dedicated intercropping systems are not restricted to cereal/grain legume mixtures, so it would certainly be appropriate to establish linkages with other strategies such as perennial grasslands and agroforestry by sharing knowledge and tools to create a generic model of the behaviour of multi-species canopies.

As a final remark, it is important to emphasize that the development of intercrops cannot take place without the assent and collaboration of all the actors in the value chain because the low degree of integration of the supply chain can be viewed as a lock-in mechanism (Fares et al. 2012) with, in particular: (i) the farmers who need technical support since the new generation of farmers may not possess the know-how to grow arable crops as intercrops and organically; (ii) the companies collecting and storing seeds which will have to adapt their collecting, sorting and storage equipment to satisfy the processors' quality demands; (iii) the industrials to adapt food processing; (iv) the breeders expected to select varieties suited to intercropping; (v) the technical institutions which must acquire and transfer operational knowledge, (vi) the researchers to produce cognitive know-how on the multiple mechanisms in play and (vii) the national and European authorities to consider relevant policy and subsidies to help reintroducing these cropping strategies.

\section{References}

Abad A, Lloveras J, Michelena A (2004) Nitrogen fertilization and foliar urea effects on durum wheat yield and quality and on residual soil nitrate in irrigated Mediterranean conditions. Field Crops Res 87: 257-269. doi:10.1016/j.fcr.2003.11.007

Agegnehu G, Ghizaw A, Sinebo W (2008) Yield potential and land-use efficiency of wheat and faba bean mixed intercropping. Agron Sustain Dev 28:257-263. doi:10.1051/agro:2008012

Altieri M (1999) The ecological role of biodiversity in agroecosystems. Agric Ecosys Environ 74:19-31. doi:10.1016/S0167-8809(99) 00028-6

Andersen MK, Hauggaard-Nielsen H, Ambus P, Jensen ES (2004) Biomass production, symbiotic nitrogen fixation and inorganic $\mathrm{N}$ use in dual and tri-component annual intercrops. Plant Soil 266:273287. doi:10.1007/s11104-005-0997-1

Anil L, Park J, Phipps RH, Miller FA (1998) Temperate intercropping of cereals for forage: a review of the potential for growth and utilization with particular reference to the UK. Grass Forage Sci 53:301-317. doi:10.1046/j.1365-2494.1998.00144.x

Banik P, Midya A, Sarkar BK, Ghose SS (2006) Wheat and chickpea intercropping systems in an additive experiment. Advantages and weed smothering. Europ J Agron 24:325-332. doi:10.1016/j.eja. 2005.10.010

Barillot R, Combes D, Chevalier V, Fournier C, Escobar-Gutierrez A (2012) How does pea architecture influence light sharing in virtual wheat-pea mixtures? A simulation study based on pea genotypes with contrasting architectures. AoB Plants. doi:10.1093/aobpla/ pls038

Barillot R, Combes D, Pineau S, Huynh P, Escobar-Gutiérrez A (2014a) Comparison of the morphogenesis of three genotypes of pea (Pisum sativum) grown in pure stands and wheat-based intercrops. AoB Plants. doi:10.1093/aobpla/plu006

Barillot R, Escobar-Gutiérrez AJ, Fournier C, Huynh P, Combes D (2014b) Assessing the effects of architectural variations on light partitioning within virtual wheat-pea mixtures. Ann Bot. doi:10. 1093/aob/mcu099

Bedoussac L (2009) Analyse du fonctionnement des performances des associations blé dur-pois d'hiver et blé dur-féverole d'hiver pour la conception d'itinéraires techniques adaptés à différents objectifs de production en systèmes bas-intrants. $\mathrm{PhD}$ thesis, INP-Toulouse

Bedoussac L, Justes E (2010a) The efficiency of a durum wheat-winter pea intercrop to improve yield and wheat grain protein concentration depends on $\mathrm{N}$ availability during early growth. Plant Soil 330:19 35. doi:10.1007/s11104-009-0082-2

Bedoussac L, Justes E (2010b) Dynamic analysis of competition and complementarity for light and $\mathrm{N}$ use to understand the yield and the protein concentration of a durum wheat-winter pea intercrop. Plant Soil 330:37-54. doi:10.1007/s11104-010-0303-8

Bedoussac L, Justes E (2011) Comparison of commonly used indices for evaluating species interactions and intercrop efficiency: application to durum wheat-winter pea intercrops. Field Crops Res 124:25-36. doi:10.1016/j.fcr.2011.05.025

Bellostas N, Hauggaard-Nielsen H, Andersen M, Jensen ES (2003) Early interference dynamics in intercrops of pea, barley and oilseed rape. Biol Agric Hor 21:337-348. doi:10.1080/ 01448765.2003.9755277

Berntsen J, Hauggaard-Nielsen H, Olesen JE, Petersen BM, Jensen ES, Thomsen A (2004) Modelling dry matter production and resource use in intercrops of pea and barley. Field Crops Res 88:69-83. doi: 10.1016/j.fcr.2003.11.012

Brisson N, Bussière F, Ozier-Lafontaine $\mathrm{H}$, Tournebize R, Sinoquet $\mathrm{H}$ (2004) Adaptation of the crop model STICS to intercropping. Theoretical basis and parameterisation. Agronomie 24:409-421. doi:10.1051/agro:2004031

Brophy L, Heichel G (1989) Nitrogen release from roots of alfalfa and soybean grown in sand culture. Plant Soil 116:77-84. doi:10.1007/ BF02327259

Bulson H, Snaydon R, Stopes C (1997) Effects of plant density on intercropped wheat and field beans in an organic farming system. $\mathrm{J}$ Agric Sci 128:59-71

Caldwell RM (1987) Plant architecture and ressource competition. Ecol Stud 61:164-179. doi:10.1007/978-3-642-71630-0 8

Carr PM, Martin GB, Caton JS, Poland W (1998) Forage and nitrogen yield of barley-pea and oat-pea intercrops. Agronomy J 90:79-84. doi:10.2134/agronj1998.00021962009000010015x

Cenpukdee U, Fukai S (1992a) Cassava/legume intercropping with contrasting cassava cultivars. 1. Competition between component crops under three intercropping conditions. Field Crops Res 29:113-133. doi:10.1016/0378-4290(92)90082-K

Cenpukdee U, Fukai S (1992b) Cassava/legume intercropping with contrasting cassava cultivars. 2. Selection criteria for cassava genotypes in intercropping with two contrasting legume crops. Field Crops Res 29:135-149. doi:10.1016/0378-4290(92)90083-L

Chalk PM, Peoples MB, McNeill AM, Boddey RM, Unkovich MJ, Gardener MJ, Silva CF, Chen D (2014) Methodologies for estimating nitrogen transfer between legume and companion species in agro-systems: a review of $15 \mathrm{~N}$ enriched techniques. Soil Biol Biochem 73:10-21. doi:10.1016/j.soilbio.2014.02. 005

Chen Y, Yu S, Yu Z (2003) Relationship between amount or distribution of PAR interception and grain output of wheat communities. Acta Agron Sin 29:730-734

Connolly J, Wayne P, Murray R (1990) Time course of plant-plant interactions in experimental mixtures of annuals - density, frequency, and nutrient effects. Oecologia 82:513-526. doi:10.1007/ BF00319795 
Corre-Hellou G (2005) Acquisition de l'azote dans des associations poisorge (Pisum sativum L. - Hordeum vulgare L.) en relation avec le fonctionnement du peuplement. $\mathrm{PhD}$ thesis, Université d'Angers

Corre-Hellou G, Crozat Y (2005) N2 fixation and N supply in organic pea (Pisum sativum L.) cropping systems as affected by weeds and peaweevil (Sitona lineatus L.). Europ J Agron 22:449-458. doi:10. 1016/j.eja.2004.05.005

Corre-Hellou G, Fustec J, Crozat Y (2006) Interspecific competition for soil $\mathrm{N}$ and its interaction with $\mathrm{N}_{2}$ fixation, leaf expansion and crop growth in pea-barley intercrops. Plant Soil 282:195-208. doi:10. 1007/s11104-005-5777-4

Corre-Hellou G, Brisson N, Launay M, Fustec J, Crozat Y (2007) Effect of root depth penetration on soil nitrogen competitive interactions and dry matter production in pea-barley intercrops given different soil nitrogen supplies. Field Crops Res 103:76-85. doi:10.1016/j. fcr.2007.04.008

Corre-Hellou G, Faure M, Launay M, Brisson N, Crozat Y (2009) Adaptation of the STICS intercrop model to simulate crop growth and $\mathrm{N}$ accumulation in pea-barley intercrops. Field Crops Res 113: 72-81. doi:10.1016/j.fcr.2009.04.007

Corre-Hellou G, Dibet A, Hauggaard-Nielsen H, Crozat Y, Gooding M, Ambus P, Dahlmann C, von Fragstein P, Pristeri A, Monti M, Jensen ES (2011) The competitive ability of pea-barley intercrops against weeds and the interactions with crop productivity and soil $\mathrm{N}$ availability. Field Crops Res 122:264-272. doi:10.1016/j.fcr.2011.04. 004

Cox GW, Atkins MD (1979) Agricultural ecology: an analysis of world food production systems. Freeman WH, San Francisco

Crews TE, Peoples MB (2004) Legume versus fertilizer sources of nitrogen: ecological tradeoffs and human needs. Agric Ecosyst Environ 102:279-297. doi:10.1016/j.agee.2003.09.018

Crozat Y, Aveline A, Coste F, Gillet J, Domenach A (1994) Yield performance and seed production pattern of field-grown pea and soybean in relation to N nutrition. Eur J Agron 3:135-144. doi:10. 1016/S1161-0301(14)80119-6

Cudney D, Jordan L, Hall A (1991) Effect of wild oat (Avena fatua) infestations on light interception and growth rate of wheat (Triticum aestivum). Weed Sci 39:175-179

Dalal RC (1974) Effects of intercropping maize with pigeon peas on grain yield and nutrient uptake. Exp Agric 10:219-224. doi:10.1017/ S0014479700000454

David C, Jeuffroy MH, Henning J, Meynard JM (2005) Yield variation in organic winter wheat: a diagnostic study in the Southeast of France. Agron Sustain Dev 25:213-223. doi:10.1051/agro:2005016

Davies B, Baulcombe D, Crute I, Dunwell J, Gale M, Jones J, Pretty J, Sutherland W, Toulmin C (2009) Reaping the benefits: science and the sustainable intensification of global agriculture. Royal Society, London

Davis JHC, Woolley JN (1993) Genotypic requirement for intercropping. Field Crops Res 34:407-430. doi:10.1016/03784290(93)90124-6

Desclaux D, Nolot JM, Chiffoleau Y, Gozé G, Leclerc C (2008) Changes in the concept of genotype $\mathrm{x}$ environment interactions to fit agriculture diversification and participatory plant breeding. Pluridisciplinary point of view. Euphytica 163:533-546. doi:10. 1007/s10681-008-9717-2

Dreccer M, Schapendonk A, Slafer G, Rabbinge R (2000) Comparative response of wheat and oilseed rape to nitrogen supply: absorption and utilisation efficiency of radiation and nitrogen during the reproductive stages determining yield. Plant Soil 220:189-205. doi:10. 1023/A:1004757124939

FAO (2010) The state of the food insecurity in the world. Addressing food insecurity in protracted crises. Food and Agriculture Organization of the United Nations. http://www.fao.org/docrep/ 013/i1683e/i1683e.pdf. Accessed 7 November 2014
Fares M, Magrini MB, Triboulet P (2012) Transition agroécologique, innovation et effets de verrouillage: le rôle de la structure organisationnelle des filières. Le cas de la filière blé dur française. Cah Agric 21:34-45. doi:10.1684/agr.2012.0539

Fujita K, Ofosubudu KG, Ogata S (1992) Biological nitrogen fixation in mixed legume-cereal cropping systems. Plant Soil 141:155-175. doi:10.1007/BF00011315

Fukai S (1993) Intercropping - bases of productivity. Field Crops Res 34: 239-245. doi:10.1016/0378-4290(93)90116-5

Fukai S, Trenbath B (1993) Processes determining intercrop productivity and yields of component crops. Field Crops Res 34:247-271. doi: 10.1016/0378-4290(93)90117-6

Fustec J, Lesuffleur F, Mahieu S, Cliquet JB (2010) Nitrogen rhizodeposition of legumes. Rev Agron Sustain Dev 30:57-66. doi:10.1051/agro/2009003

Fustec J, Jamont M, Joly FX, Piva G, Cannavacciuolo M, Cassagne N (2014) Measuring nitrogen transfer in annual intercrops. Proceedings of the European Society for Agronomy Congress

Gan YT, Liang C, Hamel C, Cutforth H, Wang H (2011) Strategies for reducing the carbon footprint of field crops for semiarid areas - a review. Agron Sustain Dev 31:643-656. doi:10.1007/s13593-0110011-7

Garnier E, Navas ML, Austin MP, Lilley JM, Gifford RM (1997) A problem for biodiversity-productivity studies: how to compare the productivity of multispecific plant mixtures to that of monocultures? Acta Oecol 18:657-670. doi:10.1016/S1146-609X(97)80049-5

Garrido-Lestache E, López-bellido RJ, López-bellido L (2004) Effect of $\mathrm{N}$ rate, timing and splitting and $\mathrm{N}$ type on bread-making quality in hard red spring wheat under rainfed Mediterranean conditions. Field Crops Res 85:213-236. doi:10.1016/S0378-4290(03)00167-9

Gastal F, Belanger G (1993) The effects of nitrogen fertilization and the growing season on photosynthesis of field-grown tall fescue (Festuca arundinacea Schreb.) canopies. Ann Bot 72:401-408

Goldberg D (1990) Components of resource competition in plant communities. In: Grace JB, Tilman D (eds) Perspectives on plant competition. Academic, San Diego, pp 27-50

Gooding MJ, Kasynova E, Ruske R, Hauggaard-Nielsen H, Jensen ES, Dahlmann C, von Fragstein Fragstein P, Dibet A, Corre Hellou G, Crozat Y, Pristeri A, Romeo M, Monti M, Launay M (2007) Intercropping with pulses to concentrate nitrogen and sulphur in wheat. J Agric Sci 145:469-479. doi:10.1017/S0021859607007241

Griffon M (2006) Nourrir la planète. Odile Jacob, Paris

Hamblin AP, Tennant D (1987) Root length density and water uptake in cereals and grain legumes: how well are they correlated. Aust J Agric Res 38:513-527. doi:10.1071/AR9870513

Hauggaard-Nielsen H, Jensen ES (2001) Evaluating pea and barley cultivars for complementarity in intercropping at different levels of soil N availability. Field Crops Res 72:185-196. doi:10.1016/ S0378-4290(01)00176-9

Hauggaard-Nielsen H, Jensen ES (2005) Facilitative root interactions in intercrops. Plant Soil 274:237-250. doi:10.1007/1-4020-4099-7_13

Hauggaard-Nielsen H, Ambus P, Jensen ES (2001a) Temporal and spatial distribution of roots and competition for nitrogen in pea-barley intercrops - a field study employing P-32 technique. Plant Soil 236:63-74. doi:10.1023/A:1011909414400

Hauggaard-Nielsen H, Ambus P, Jensen ES (2001b) Interspecific competition, $\mathrm{N}$ use and interference with weeds in pea-barley intercropping. Field Crops Res 70:101-109. doi:10.1016/S03784290(01)00126-5

Hauggaard-Nielsen H, Ambus P, Jensen ES (2003) The comparison of nitrogen use and leaching in sole cropped versus intercropped pea and barley. Nutr Cycl Agroecosyst 65:289-300. doi:10.1023/ A:1022612528161

Hauggaard-Nielsen H, Andersen MK, Jørnsgard B, Jensen ES (2006) Density and relative frequency effects on competitive interactions 
and resource use in pea-barley intercrops. Field Crops Res 95:256267. doi:10.1016/j.fcr.2005.03.003

Hauggaard-Nielsen H, Jørnsgard B, Kinane J, Jensen ES (2007) Grain legume-cereal intercropping: the practical application of diversity, competition and facilitation in arable and organic cropping systems. Renewable Agric Food Syst 23:3-12. doi:10.1017/ S1742170507002025

Hauggaard-Nielsen H, Gooding M, Ambus P, Corre-Hellou G, Crozat Y, Dahlmann C, Dibet A, von Fragstein P, Pristeri A, Monti M, Jensen ES (2009a) Pea-barley intercropping and short-term subsequent crop effects across European organic cropping conditions. Nutr Cycl Agroecosyst 85:141-155. doi: 10.1007/s10705-009-9254-y

Hauggaard-Nielsen H, Gooding M, Ambus P, Corre-Hellou G, Crozat Y, Dahlmann C, Dibet A, von Fragstein P, Pristeri A, Monti M, Jensen ES (2009b) Pea-barley intercropping for efficient symbiotic N2fixation, soil $\mathrm{N}$ acquisition and use of other nutrients in European organic cropping systems. Field Crops Res 113:64-71. doi:10.1016/ j.fcr.2009.04.009

Hinsinger P (2001) Bioavailability of soil inorganic P in the rhizosphere as affected by root-induced chemical changes: a review. Plant Soil 237:173-195. doi:10.1023/A:1013351617532

Hogh-Jensen H, Schjoerring JK (2001) Rhizodeposition of nitrogen by red clover, white clover and ryegrass leys. Soil Biol Biochem 33: 439-448. doi:10.1016/S0038-0717(00)00183-8

IAASTD (2009) International assessment of agricultural knowledge, science and technology for development. Global Report. http:// apps.unep.org/publications/pmtdocuments/-Agriculture $\% 20$ at $\%$ $20 \mathrm{a} \% 20$ crossroads $\% 20-\% 20$ Synthesis $\% 20$ report-2009Agriculture at_Crossroads_Synthesis_Report.pdf Accessed 7 November 2014

Jackson W, Piper J (1989) The necessary marriage between ecology and agriculture. Ecology 70:1591-1593. doi:10.2307/1938090

Jahansooz MR, Yunusa IAM, Coventry DR, Palmer AR, Eamus D (2007) Radiation- and water-use associated with growth and yields of wheat and chickpea in sole and mixed crops. Eur J Agron 26:275-282. doi: 10.1016/j.eja.2006.10.008

Jamont M, Piva G, Fustec J (2013) Sharing N resources in the early growth of rapeseed intercropped with faba bean: does $\mathrm{N}$ transfer matter? Plant Soil 371:641-653. doi:10.1007/s11104-013-1712-2

Jensen ES (1996a) Grain yield, symbiotic N2 fixation and interspecific competition for inorganic N in pea-barley intercrops. Plant Soil 182: 25-38. doi:10.1007/BF00010992

Jensen ES (1996b) Barley uptake of N deposited in the rhizosphere of associated field pea. Soil Biol Biochem 28:159-168. doi:10.1016/ 0038-0717(95)00134-4

Johansen A, Jensen ES (1996) Transfer of N and P from intact or decomposing roots of pea to barley interconnected by an arbuscular mycorrhizal fungus. Soil Biol Biochem 28:73-81. doi:10.1016/ 0038-0717(95)00117-4

Jolliffe PA (2000) The replacement series. J Ecol 88:371-385. doi:10. 1046/j.1365-2745.2000.00470.x

Jolliffe PA, Wanjau FM (1999) Competition and productivity in crop mixtures: some properties of productive intercrops. J Agric Sci 132: 425-435

Justes E, Beaudoin N, Bertuzzi P, Charles R, Constantin J, Dürr C, Hermon C, Joannon A, Le Bas C, Mary B, Mignolet C, Montfort F, Ruiz L, Sarthou JP, Souchère V, Tournebize J, Savini I, Réchauchère $O$ (2012) Réduire les fuites de nitrate au moyen de cultures intermédiaires : conséquences sur les bilans d'eau et d'azote, autres services écosystémiques. Synthèse du rapport d'étude, INRA. https://www6.paris.inra. fr/depe/Media/Fichier/Etudes/Interculture/Synthese-ITC Accessed 7 November 2014

Khan WDF, Peoples MB, Herridge DF (2002a) Quantifying belowground nitrogen of legumes-1. Optimising procedures for N-15 shoot-labelling. Plant Soil 245:327-334. doi:10.1023/ A:1020407006212

Khan DF, Peoples MB, Chalk PM, Herridge DF (2002b) Quantifying below-ground nitrogen of legumes. 2. A comparison of N-15 and non isotopic methods. Plant Soil 239:277-289. doi:10.1023/ A: 1015066323050

Kim S, Dale BE (2005) Life cycle assessment of various cropping systems utilized for producing biofuels: bioethanol and biodiesel. Biomass Bioenerg 29:426-439. doi:10.1016/j.biombioe.2005.06. 004

Kiniry J, Jones C, O'Toole J, Blanchet R, Cabelguenne M, Spanel D (1989) Radiation-use efficiency in biomass accumulation prior to grain-filling for five grain-crop species. Field Crops Res 20:51-64. doi:10.1016/0378-4290(89)90023-3

Knudsen MT, Hauggaard-Nielsen H, Jørnsgard B, Jensen ES (2004) Comparison of interspecific competition and $\mathrm{N}$ use in pea-barley, faba bean-barley and lupin-barley intercrops grown at two temperate locations. J Agric Sci 142:617-627. doi:10.1017/S0021859604004745

Launay M, Brisson N, Satger S, Hauggaard-Nielsen H, Corre-Hellou G, Kasynova E, Ruske R, Jensen ES, Gooding MJ (2009) Exploring options for managing strategies for pea-barley intercropping using a modeling approach. Europ J Agron 31:85-98. doi:10.1016/j.eja. 2009.04.002

Lemaire G, Gastal F (1997) N uptake and distribution in plant canopies. In: Lemaire G (ed) Diagnosis of the nitrogen status in crops. Springer, Heidelberg, pp 3-43

Lesuffleur F, Salon C, Jeudy C, Cliquet JB (2013) Use of a 15 N2 labelling technique to estimate exudation by white clover and transfer to companion ryegrass of symbiotically fixed N. Plant Soil 369: 187-197. doi:10.1007/s11104-012-1562-3

Liebman M (1988) Ecological suppression of weeds in intercropping systems: a review. In: Altieri MA, Liebman M (eds) Weed management in agroecosystems: ecological approaches. CRC Press, Boca Raton, pp 197-212

Liebman M, Davis A (2000) Integration of soil, crop and weed management in low-external-input farming systems. Weed Res 40:27-47. doi:10.1046/j.1365-3180.2000.00164.x

Liebman M, Dyck E (1993) Crop rotation and intercropping strategies for weed management. Ecol Appl 3:92-122. doi:10.2307/ 1941795

Lithourgidis AS, Vasilakoglou IB, Dhima KV, Dordas CA, Yiakoulaki MD (2006) Forage yield and quality of common vetch mixtures with oat and triticale in two seeding ratios. Field Crops Res 99:106-113. doi:10.1016/j.fcr.2006.03.008

Loomis RS, Williams WA (1963) Maximum crop productivity: an estimate. Crop Sci 3:67-72. doi:10.2135/cropsci1963. 0011183X000300010021x

Mahieu S (2007) Assessment of the below ground contribution of field grown pea (Pisum sativum L.) to the soil $\mathrm{N}$ pool. PhD thesis, Université d'Angers

Mahon JD, Child JJ (1979) Growth response of inoculated peas (Pisum sativum) to combined nitrogen. Can J Bot 57:1687-1693. doi:10. $1139 / \mathrm{b} 79-206$

Malézieux E, Crozat Y, Dupraz C, Laurans M, Makowski D, OzierLafontaine H, Rapidel B, de Tourdonnet S, Valantin-Morison M (2009) Mixing plant species in cropping systems: concepts, tools and models. A review. Agron Sustain Dev 29:43-62. doi:10.1051/ agro:2007057

Mayer J, Buegger F, Jensen E, Schloter M, Hess J (2003) Residual nitrogen contribution from grain legumes to succeeding wheat and rape and related microbial process. Plant Soil 255:541-554. doi:10. 1023/A:1026081015076

Mcdonald GK (2003) Competitiveness against grass weeds in field pea genotypes. Weed Res 43:48-58. doi:10.1046/j.1365-3180.2003. 00316.x 
Mead R, Willey RW (1980) The concept of a 'land equivalent ratio' and advantages on yields from intercropping. Exp Agric 16:217-228. doi:10.1017/S0014479700010978

Midmore DJ (1993) Agronomic modification of resource use and intercrop productivity. Field Crops Res 34:357-380. doi:10.1016/03784290(93)90122-4

Mohta NK, De R (1980) Intercropping maize and sorghum with soya beans. J Agric Sci 95:117-122. doi:10.1017/S0021859600029348

Monteith J (1977) Climate and the efficiency of crop production in Britain. Phil Trans R Soc Lond B 281:277-294. doi:10.1098/rstb. 1977.0140

Natarajan M, Willey R (1980a) Sorghum-pigeonpea intercropping and the effects of plant population density. 1. Growth and yield. J Agric Sci 95:51-58. doi:10.1017/S0021859600029269

Natarajan M, Willey R (1980b) Sorghum-pigeonpea intercropping and the effects of plant population density. 2. Resource use. J Agric Sci 95:59-65. doi:10.1017/S0021859600029270

Naudin C, Aveline A, Corre-Hellou G, Dibet A, Jeuffroy MH, Crozat Y (2009) Agronomic analysis of the performance of spring and winter cereal-legume intercrops in organic farming. J Agric Sci Tech 3:1728

Naudin C, Corre-Hellou G, Pineau S, Crozat Y, Jeuffroy MH (2010) The effect of various dynamics of $\mathrm{N}$ availability on winter pea-wheat intercrops: crop growth, $\mathrm{N}$ partitioning and symbiotic $\mathrm{N}_{2}$ fixation. Field Crops Res 119:2-11. doi:10.1016/j.fcr.2010.06.002

Naudin C, van der Werf HMG, Jeuffroy MH, Corre-Hellou G (2014) Life cycle assessment applied to pea-wheat intercrops: a new method for handling the impacts of co-products. J Clean Prod 73:80-87. doi:10. 1016/j.jclepro.2013.12.029

Nelson SC, Robichaux RH (1997) Identifying plant architectural traits associated with yield under intercropping: implications of cultivarcropping system interactions. Plant Breed 116:163-170. doi:10. 1111/j.1439-0523.1997.tb02172.x

Nieder R, Benbi DK (2008) Carbon and nitrogen in the terrestrial environment. Springer, Heidelberg

Niggli U, Fließbach A, Hepperly P, Scialabba N (2009) Low greenhouse gas agriculture: mitigation and adaptation potential of sustainable farming systems. Food and Agriculture Organization of the United Nations. http://www.fcrn.org.uk/ sites/default/files/low-greenhouse-gas-agriculture.pdf. Accessed 7 November 2014

O'Leary N, Smith ME (1999) Breeding corn for adaptation to two diverse intercropping companions. Am J Altern Agric 14:158-164. doi:10. 1017/S0889189300008328

Oelhermann M, Echarte L, Vachon K, Dubois C (2009) The role of complex agroecosystems in sequestering carbon and mitigating global warming. Earth Environ Sci 6:20-31. doi:10.1088/1755$1307 / 6 / 24 / 242031$

Ofori F, Stern WR (1987) Cereal-legume intercropping systems. Adv Agron 41:41-90

Padulosi S, Hodgkin T, Williams JT, Haq N (2002) Underutilized crops: trends, challenges and opportunities in the 21st century. In: Engels JMM, Ramanatha Rao V, Brown AHD, Jackson MT (eds) Managing plant genetic resources. CAB International, Wallingford, pp 323-338

Pardey PG, Pingali PL (2010) Reassessing international agricultural research for food and agriculture. Report prepared for GCARD. http://www.fao.org/docs/eims/upload/278047/3568_Pardey Pingali_2010_GCARD_text_figs_tabs_1_.pdf. Accessed 7 November $201 \overline{4}$

Paynel F, Murray P, Cliquet J (2001) Root exudates: a pathway for shortterm N transfer from clover and ryegrass. Plant Soil 229:235-243. doi:10.1023/A:1004877214831

Paynel F, Lesuffleur F, Bigot J, Diquelou S, Cliquet JB (2008) A study of $15 \mathrm{~N}$ transfer between legumes and grasses. Agron Sustain Dev 28: 281-290. doi:10.1051/agro:2007061
Peoples MB, Hauggaard-Nielsen H, Jensen ES (2009) The potential environmental benefits and risks derived from legumes in rotations. In: Emerich DW, Krishnan HB (eds) Nitrogen fixation in crop production. American Society of Agronomy, Madison, pp $349-385$

Poggio SL (2005) Structure of weed communities occurring in monoculture and intercropping of field pea and barley. Agric Ecosyst Environ 109:48-58. doi:10.1016/j.agee.2005.02.019

Prescott-Allen R, Prescott-Allen C (1990) How many plants feed the world? Conservation Biol 4:365-374. doi:10.1111/j.1523-1739. 1990.tb00310.x

PROLEA (2013) Statistiques des oléagineux et protéagineux 2012-2013. http://www.prolea.com/fileadmin/internet/fichiers/chiffres/de-laproduction-a-la-consommation-2012-2013.pdf. Accessed 7 November 2014

Qin AZ, Huang GB, Chai Q, Yu AZ, Huang P (2013) Grain yield and soil respiratory response to intercropping systems on arid land. Field Crops Res 144:1-10. doi:10.1016/j.fcr.2012.12.005

Ratnadass A, Fernandes P, Avelino J, Habib R (2012) Plant species diversity for sustainable management of crop pests and diseases in agroecosystems: a review. Agron Sustain Dev 32:273-303. doi:10. 1007/s13593-011-0022-4

Sagan M, Ney B, Duc G (1993) Plant symbiotic mutants as a tool to analyse nitrogen and yield relationship in field-grown peas (Pisum sativum L.). Plant Soil 153:33-45. doi:10.1007/BF00010542

Samaan J, El-Khayat GH, Manthey FA, Fuller MP, Brennan CS (2006) Durum wheat quality: II. The relationship of kernel physicochemical composition to semolina quality and end product utilisation. Int $\mathrm{J}$ Food Sci Technol 41:47-55. doi:10.1111/j.1365-2621.2006.01313.

Sebillotte M (1974) Agronomie et agriculture. Essai d'analyse des tâches de l'agronome. Cah ORSTOM sér Biol 24:3-25

Shibles RM, Weber CR (1966) Interception of solar radiation and dry matter production by various soybean planting patterns. Crop Sci 6 : 55-59. doi:10.2135/cropsci1966.0011183X000600010017x

Sinoquet H, Caldwell RM (1995) Estimation of light capture and partitioning in intercropping systems. In: Sinoquet $\mathrm{H}$, Cruz $\mathrm{P}$ (eds) Ecophysiologie of tropical intercropping. INRA, Paris, pp 79-97

Sivakumar MV, Virmani S (1980) Growth and resource use of maize, pigeon pea and maize/pigeonpea intercrop in an operational research watershed. Exp Agric 16:377-386. doi:10.1017/ S0014479700012035

Sivakumar MV, Virmani S (1984) Crop productivity in relation to interception of photosynthetically active radiation. Agric Forest Meteorology 31:131-141. doi:10.1016/0168-1923(84)90015-7

Spitters C, Aerts R (1983) Simulation of competition for light and water in crop-weed associations. Aspects Appl Biol 4:467-483

Stern W (1993) Nitrogen fixation and transfer in intercrop systems. Field Crops Res 34:335-356. doi:10.1016/0378-4290(93)90121-3

Tofinga M, Paolini R, Snaydon R (1993) A study of root and shoot interactions between cereals and peas in mixtures. J Agric Sci 120: 13-24. doi:10.1017/S0021859600073548

Townley-Smith L, Wright AT (1994) Field pea cultivar and weed response to crop seed rate in western Canada. Can J Plant Sci 76:907914. doi:10.4141/cjps94-074

Trenbath BR (1986) Resource use by intercrops. In: Francis CA (ed) Multiple cropping systems. Macmillan, New York, pp 57-81

Trenbath BR (1993) Intercropping for the management of pests and diseases. Field Crops Res 34:381-405. doi:10.1016/03784290(93)90123-5

Tricot F, Crozat Y, Pellerin S (1997) Root system growth and nodule establishment on pea (Pisum sativum L.). J Exp Bot 48:1935-1941. doi:10.1093/jxb/48.11.1935

Tsubo M, Walker S (2002) A model of radiation interception and use by a maize-bean intercrop canopy. Agric Forest Meteorology 110:203215. doi:10.1016/S0168-1923(01)00287-8 
Tsubo M, Walker S, Mukhala E (2001) Comparisons of radiation use efficiency of mono-/inter-cropping systems with different row orientations. Field Crops Res 71:17-29. doi:10.1016/S0378-4290(01) 00142-3

Vandermeer J (1989) The ecology of intercropping. Cambridge University Press, Cambridge

Vandermeer J (1995) The ecological basis of alternative agriculture. Annu Rev Ecol Syst 26:201-224. doi:10.1146/annurev.es.26.110195. 001221

Vandermeer J, van Noordwijk M, Anderson J, Ong C, Perfecto I (1998) Global change and multi-species agroecosystems: concepts and issues. Agric Ecosyst Environ 67:1-22. doi:10.1016/S01678809(97)00150-3

Voisin AS, Salon C, Munier-Jolain NG, Ney B (2002) Quantitative effects of soil nitrate, growth potential and phenology on symbiotic nitrogen fixation of pea (Pisum sativum L.). Plant Soil 243:31-42. doi:10.1023/A:1019966207970

Wacquant J, Ouknider M, Jacquard P (1989) Evidence for a periodic excretion of nitrogen by roots of grass-legume associations. Plant Soil 116:57-68. doi:10.1007/BF02327257

Wall D, Friesen GH, Bhati TK (1991) Wild mustard interference in traditional and semi-leafless field peas. Can J Plant Sci 71:473480. doi:10.4141/cjps91-064

Walter A, Lebot V (2003) Jardins d'Océanie. IRD Editions, Paris
Weigelt A, Jolliffe P (2003) Indices of plant competition. J Ecol 91:707720. doi:10.1046/j.1365-2745.2003.00805.x

White JG, Scott TW (1991) Effects of perennial forage-legume living mulches on no-till winter wheat and rye. Field Crops Res 28:135148. doi:10.1016/0378-4290(91)90079-B

Willey RW (1979a) Intercropping-its importance and research needs. 1. Competition and yield advantages. Field Crop Abstr 32:1-10

Willey RW (1979b) Intercropping - its importance and research needs. 2. Agronomy and research needs. Field Crop Abstr 32:73-85

Willey RW (1990) Resource use in intercropping systems. Agric Water Manag 1:215-231. doi:10.1016/0378-3774(90)90069-B

Willey RW, Osiru D (1972) Studies on mixtures of maize and beans (Phaseolus vulgaris) with particular reference to plant population. $\mathrm{J}$ Agric Sci 79:517-529

Williams AC, McCarthy BC (2001) A new index of interspecific competition for replacement and additive designs. Ecol Res 16:29-40. doi:10.1046/j.1440-1703.2001.00368.x

Wilson J (1988) Shoot competition and root competition. J Appl Ecol 25: 279-296. doi:10.2307/2403626

Xiao Y, Li L, Zhang F (2004) Effect of root contact on interspecific competition and $\mathrm{N}$ transfer between wheat and fababean using direct and indirect $15 \mathrm{~N}$ techniques. Plant Soil 262:45-54. doi:10.1023/ B:PLSO.0000037019.34719.0d 